\title{
Anisotropic Platinum Nanoparticle-Induced Cytotoxicity, Apoptosis, Inflammatory Response, and Transcriptomic and Molecular Pathways in Human Acute Monocytic Leukemia Cells
}

\author{
Sangiliyandi Gurunathan ${ }^{\circledR}$, Muniyandi Jeyaraj, Hyeonwoo La, Hyunjin Yoo, Youngsok Choi $\odot$, \\ Jeong Tae Do®, Chankyu Park, Jin-Hoi Kim $₫$ and Kwonho Hong * \\ Department of Stem Cell and Regenerative Biotechnology and Humanized Pig Center (SRC), \\ Konkuk Institute of Technology, Konkuk University, Seoul 05029, Korea; gsangiliyandi@yahoo.com (S.G.); \\ muniyandij@yahoo.com (M.J.); hyunwoo1001@naver.com (H.L.); hyunjinyoo7@gmail.com (H.Y.); \\ choiys3969@konkuk.ac.kr (Y.C.); dojt@konkuk.ac.kr (J.T.D.); chankyu@konkuk.ac.kr (C.P.); \\ jhkim541@konkuk.ac.kr (J.-H.K.) \\ * Correspondence: hongk@konkuk.ac.kr; Tel.: +82-2-450-0560; Fax: +82-2-444-3490
}

Received: 27 November 2019; Accepted: 7 January 2020; Published: 9 January 2020

\begin{abstract}
The thermoplasmonic properties of platinum nanoparticles (PtNPs) render them desirable for use in diagnosis, detection, therapy, and surgery. However, their toxicological effects and impact at the molecular level remain obscure. Nanotoxicology is mainly focused on the interactions of nanostructures with biological systems, particularly with an emphasis on elucidating the relationship between the physical and chemical properties such as size and shape. Therefore, we hypothesized whether these unique anisotropic nanoparticles could induce cytotoxicity similar to that of spherical nanoparticles and the mechanism involved. Thus, we synthesized unique and distinct anisotropic PtNPs using lycopene as a biological template and investigated their biological activities in model human acute monocytic leukemia (THP-1) macrophages. Exposure to PtNPs for $24 \mathrm{~h}$ dose-dependently decreased cell viability and proliferation. Levels of the cytotoxic markers lactate dehydrogenase and intracellular protease significantly and dose-dependently increased with PtNP concentration. Furthermore, cells incubated with PtNPs dose-dependently produced oxidative stress markers including reactive oxygen species (ROS), malondialdehyde, nitric oxide, and carbonylated protein. An imbalance in pro-oxidants and antioxidants was confirmed by significant decreases in reduced glutathione, thioredoxin, superoxide dismutase, and catalase levels against oxidative stress. The cell death mechanism was confirmed by mitochondrial dysfunction and decreased ATP levels, mitochondrial copy numbers, and PGC- $1 \alpha$ expression. To further substantiate the mechanism of cell death mediated by endoplasmic reticulum stress (ERS), we determined the expression of the inositol-requiring enzyme (IRE1), (PKR-like ER kinase) PERK, activating transcription factor 6 (ATF6), and activating transcription factor 4 ATF4, the apoptotic markers p53, Bax, and caspase 3 , and the anti-apoptotic marker Bcl-2. PtNPs could activate ERS and apoptosis mediated by mitochondria. A proinflammatory response to PtNPs was confirmed by significant upregulation of interleukin-1-beta (IL-1 $\beta)$, interferon $\gamma(\mathrm{IFN} \gamma)$, tumor necrosis factor alpha (TNF $\alpha)$, and interleukin (IL-6). Transcriptomic and molecular pathway analyses of THP-1 cells incubated with the half maximal inhibitory concentration $\left(\mathrm{IC}_{50}\right.$ ) of PtNPs revealed the altered expression of genes involved in protein misfolding, mitochondrial function, protein synthesis, inflammatory responses, and transcription regulation. We applied transcriptomic analyses to investigate anisotropic PtNP-induced toxicity for further mechanistic studies. Isotropic nanoparticles are specifically used to inhibit non-specific cellular uptake, leading to enhanced in vivo bio-distribution and increased targeting capabilities due to the higher radius of curvature. These characteristics of anisotropic nanoparticles could enable the technology as an attractive platform for nanomedicine in biomedical applications.
\end{abstract}


Keywords: platinum nanoparticles; oxidative stress; mitochondrial dysfunction; endoplasmic reticulum stress; apoptosis; proinflammatory response; transcriptomic analysis; molecular pathway analysis

\section{Introduction}

Over the past decade, both academia and industry became interested in the development of novel nanoparticles (NPs) to detect and/or treat cancer and other infectious diseases [1,2], and efforts were directed toward the development of unique nano-sized materials. Due to their enhanced surface area-to-volume ratio, NPs have unique physicochemical properties and characteristic features compared with their bulk counterparts, such as augmented catalytic potential, distinctive plasmonic signatures, and enhanced transport capabilities that could be suitable for medical and industrial applications. Inorganic, notably metal NPs attracted research interest due their convenience and potential for specific targeting and sustained release [3]. Biologically synthesized NPs can be used for various purposes, but they are associated with undesirable side effects and solubility. Among various types of NPs, platinum NPs (PtNPs) have thermoplasmonic and catalytic potential, and they can serve as a source for the development of nano-based materials [4]. Platinum NPs are included in cosmetics, supplements, food additives, electrocatalytic processes, data storage systems, electronic devices, electrochemical biosensors, and chemical, fluorescence, and refractometry sensors [5-7]. Furthermore, PtNPs have biomedical applications as diagnostic mediators, medical implants, drug delivery vehicles, and photothermal therapy as they are less cytotoxic than other metal nanoparticles such as silver [8-11]. The biological responses of PtNPs depend on their physicochemical properties, including size, shape, surface moiety, core composition, and morphology [12]. Several studies showed that responses to NPs in vitro include cellular death, the activation of stress, inflammatory, and immune responses, cytotoxicity, genotoxicity, developmental abnormalities, the modification of gene transcription, and the modulation of signal transduction pathways $[13,14]$. Notably, PtNPs are both biocompatible with and cytotoxic to various types of human cells [15-18]. For instance, PtNPs can act as scavengers of reactive oxygen species (ROS) $[19,20]$, and they induce developmental alterations and increase heart rates in zebrafish [21]. Ultra-small PtNPs induce cellular stress, cytotoxicity, DNA damage, and genotoxicity in vivo and in vitro in human monocytic [22], U2OS [18], and prostate cancer (LNCaP) cell lines [17].

Platinum-based NPs with attractive electrocatalytic properties [23,24] can function as catalysts and have therapeutic applications. They induce apoptosis by targeting specific signaling pathways [25], and they induce cytotoxicity in human colon carcinoma HT29 and Caco-2 cell lines, as well as the death of cervical cancer cells through mitotic G2 phase (G2/M) phase arrest $[5,26]$. Furthermore, PtNPs induce DNA damage in human cancerous and normal cells including colon cancer [27], monocytic [22], U2OS [18], cancer (LNCaP) [17], trophoblasts [28], and bronchial epithelial [29] cells. They also induce apoptosis through G0/G1 cell cycle arrest in the human breast adenocarcinoma cell line, MCF-7 [30]. Platinum NPs inhibit the activity of Taq DNA polymerase and damage DNA structures [31]. Human bronchial epithelium (BEAS-2B) and human lung alveolar type II epithelioid cells (A549) lose viability when incubated with PtNPs, and interleukin-8 (IL-8) concentrations increase remarkably [32]. Platinum NPs induce size-dependent toxicity in neuroblastoma, MDA-MB-231, and LNCaP cells, indicating that the diameter of these NPs plays a crucial role in cytotoxicity [33]. Graphene oxide and vanillin-functionalized graphene oxide induce pro-inflammatory cytokines in a human acute monocytic leukemia cell line [22], and PtNPs dose-dependently induce cytokines such as IL-1 $\beta$, IL-8, and tumor necrosis factor alpha (TNF $\alpha)$ [34].

Findings of PtNP-induced reactions in cellular systems suggest that further evaluation is required to gain a deeper understanding of the biological responses induced by PtNPs, particularly those of an anisotropic nature, to ensure safety when applied in vivo. Biological PtNPs are needed to explore transcriptomic and molecular pathways in THP-1 cell lines. Transcriptome sequencing (RNA-seq) 
is a powerful tool for investigating genes and proteins at the levels of transcription and translation, respectively, as well as the molecular mechanisms of THP-1 after incubation with PtNPs. It is particularly useful for studying routinely applied nanoparticles such as PtNPs, since RNA-seq allows global examination of biological responses through gene expression. The expression of genes involved in metal metabolism was disrupted, as well as that of genes acting in transcription regulation and DNA binding, and clusters of genes associated with protein synthesis and structure are altered in THP-1 cells incubated with zinc oxide nanoparticles [35]. Several research groups investigated the toxicity of PtNPs because of their broad range of applications, but most of them were qualitative, showing, for example, that PtNPs induce cell death. However, a comprehensive approach to PtNP-induced cellular toxicity, apoptosis, and immunomodulation, and the transcriptome and molecular pathways involved in these effects of anisotropic PtNPs in THP-1 was not undertaken. Macrophages generally play critical roles in innate immune defense, having a powerful phagocytic capacity, and residing in many tissues. Such features render them appropriate for investigations into the toxicological impact of NPs in vitro [35,36]. Generally, nanoparticles are highly toxic. The toxic effect may be caused by their unique physical and chemical properties, which underlie specific mechanisms of interaction with living systems. In general, this determines the importance of studying the causes and mechanisms of the potential toxic effect of NPs. Normally, anisotropic nanoparticles have enhanced physical, chemical, and biological properties compared to spherical nanoparticles, including increased targeting avidity and decreased non-specific in vivo clearance compared to spherical nanoparticles.

With these desirable and specific features of PtNP properties, anisotropic nanoparticles were successfully utilized to study biological effects in many biomedical settings, and these particles seem to be better than analogous spherical nanoparticles. Therefore, we evaluated anisotropic PtNP-induced cytotoxicity, apoptosis, and pro-inflammatory responses, and analyzed transcriptomic and molecular pathways in the human acute monocytic leukemia cell line THP-1.

\section{Results and Discussion}

\subsection{Synthesis and Characterization of PtNPs Using Lycopene}

The main aim of PtNP synthesis using lycopene was to create non-toxic, secondary plant metabolites that are environmentally friendly and non-pollutant. Various types of NPs were synthesized using extracts of plant and microbes, as well as pure proteins, amines, amino acids, phenols, sugars, ketones, aldehydes, and carboxylic acids. We synthesized NPs in aqueous mixtures of $1 \mathrm{mM}$ $\mathrm{H}_{2} \mathrm{PtCl}_{6} \cdot 6 \mathrm{H}_{2} \mathrm{O}$ and $1 \mathrm{mg} / \mathrm{mL}$ lycopene at $70{ }^{\circ} \mathrm{C}$ for $1 \mathrm{~h}$ in sealed flasks to avoid evaporation. Identical amounts of platinum and lycopene solutions were separately maintained under the same reaction conditions as controls.

We initially confirmed that reduced Pt ions were incorporated into PtNPs as a change of color from yellow to dark brown, indicating the formation of palladium NP, and we then characterized the PtNPs using ultra-violet (UV)-visible light spectroscopy. An absorption peak in the 275-325 nm range of the UV-visible spectrum was characteristic of the surface plasmon resonance (SPR) band of PtNPs (Figure 1A). This suggested that lycopene reduced Pt ions and formed stable PtNPs. Others also showed that polyvinylpyrrolidone (PVP) [37], apigenin [22], and tangeretin [18] can reduce Pt and stabilize PtNPs.

Figure $1 \mathrm{~B}$ shows that crystalline PtNPs had the features of a Pt face-centered cubic (fcc) phase. First (111), second (200), and third (220) peaks corresponded to $2 \theta$ values of $41.9^{\circ}, 46.5^{\circ}$, and $67.5^{\circ}$, respectively. The X-ray diffraction (XRD) peaks of PtNPs were broad and comparable to those of the corresponding bulk Pt material. The average size of Pt nanocrystallites was calculated from each XRD peak using the width of reflection according to the Debye-Scherrer equation. The particle size of polyhedral and anisotropic PtNPs was analyzed using transmission electron microscopy (TEM) to ensure a nanosized particle range of $5-45 \mathrm{~nm}$. Over $90 \%$ of the PtNPs were polyhedral (spheres, 
cubes, rectangles, triangles, octahedrons, and tetrahedral or truncated cubic hexagons, octahedrons and tetrahedrons) with very sharp corners, edges, and facets.
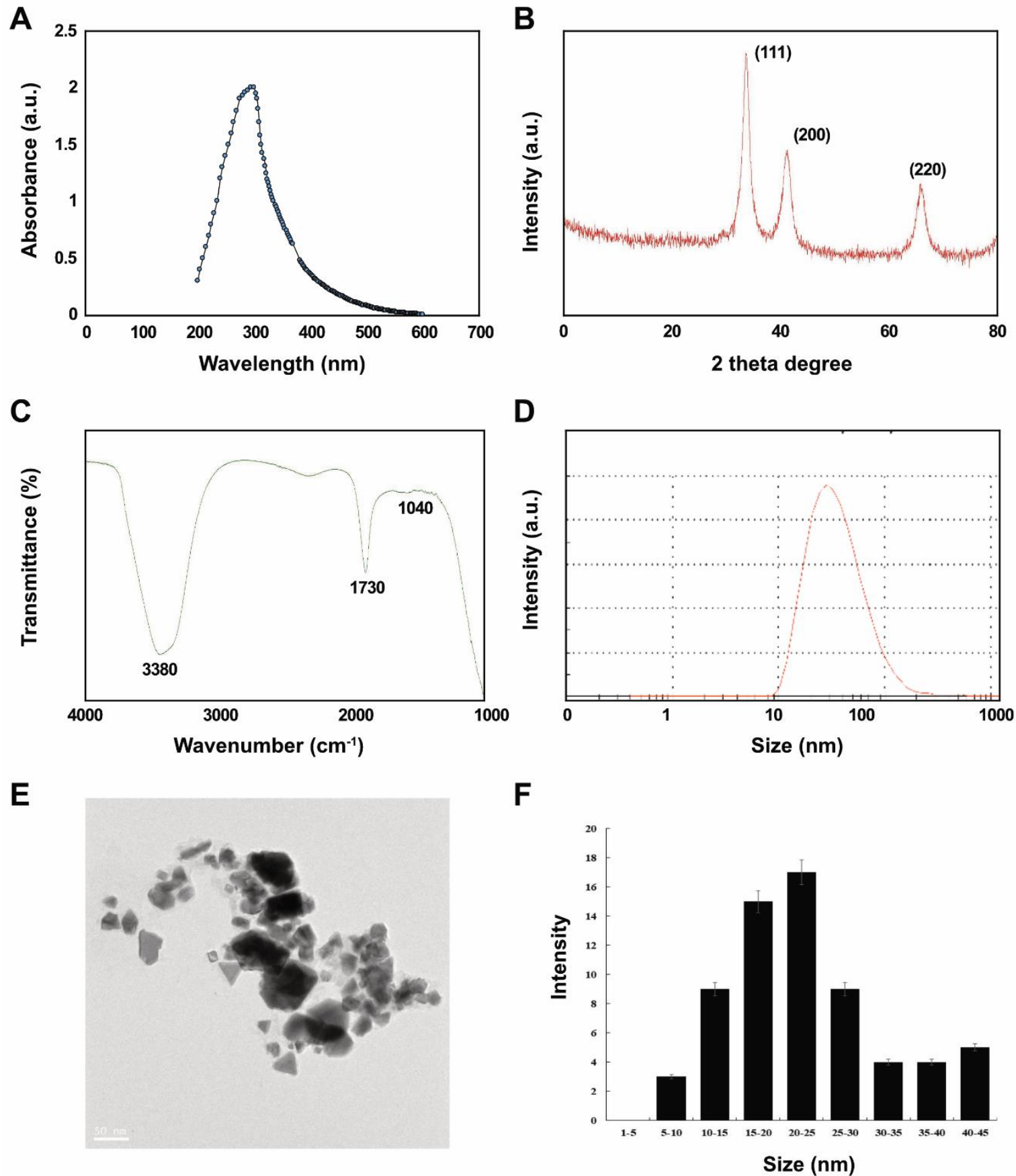

Figure 1. Synthesis and characterization of platinum nanoparticles (PtNPs) using lycopene. (A) Absorption spectra of lycopene-mediated synthesis of PtNPs. (B) X-ray diffraction (XRD) patterns of PtNPs. (C) Fourier-transform infrared (FTIR) spectra of PtNPs. (D) Size distribution analysis of PtNPs using dynamic light scattering (DLS). (E) TEM images of PtNPs. (F) Histograms showing particle size distribution. At least three independent experiments were performed for each sample, and reproducible results were obtained. The data represent the results of a representative experiment.

We then aimed to identify biomolecules in lycopene that might be responsible for reducing chloroplatinic acid ions and capping NP surfaces using Fourier-transform infrared spectroscopy (FTIR). The capping reagent responsible for the stability of the biomolecule reduced PtNPs. The interaction 
between PtNPs and lycopene generated peaks at 1730 and $3380 \mathrm{~cm}^{-1}$. Relative shifts in position and intensity distribution were confirmed by FTIR. This showed that the proteins capped the surface of the nanoparticles and stabilized them for longer periods. Figure $1 \mathrm{C}$ shows that the IR bands at $1730 \mathrm{~cm}^{-1}$ and $3380 \mathrm{~cm}^{-1}$ were characteristic of the $\mathrm{C}=\mathrm{O}$ stretching mode of the carboxylic acid group and the $\mathrm{O}-\mathrm{H}$ stretching mode, respectively $[38,39]$. The band due to $\mathrm{C}-\mathrm{O}$ stretching merged into a very broad envelope centered on $1040 \mathrm{~cm}^{-1}$, arising from $\mathrm{C}-\mathrm{O}-\mathrm{C}$ symmetric stretching and the $\mathrm{C}-\mathrm{O}-\mathrm{H}$ bending vibrations of lycopene. The $\mathrm{C}=\mathrm{O}$ stretching mode indicated that a $-\mathrm{COOH}$ group in the material bound to PtNPs. Thus, the bands at 1730 and $1040 \mathrm{~cm}^{-1}$ in FTIR indicated that PtNPs bind to proteins via free amine groups.

The average size of synthesized PtNPs measured as dynamic light scattering was 30 (range, 10-100) $\mathrm{nm}$, which was slightly larger than that determined by TEM due to Brownian motion of the suspended particles (Figure 1D). The mean hydrodynamic diameter of PtNPs was $25.5 \pm 5 \mathrm{~nm}$ with a polydispersity index of $0.150 \pm 0.015$. Furthermore, we performed size distribution analysis in various solutions such as water, Roswell Park Memorial Institute Medium (RPMI) medium, and RPMI medium with $10 \%$ fetal bovine serum (FBS) using dynamic light scattering (DLS) assay. It was found that the average size of PtNPs was $25.5 \pm 5,60 \pm 11.0$, and $40 \pm 5.0 \mathrm{~nm}$ in water, RPMI medium, and RPMI medium with $10 \%$ serum, respectively. The results suggest that the PtNPs particles dissolved in RPMI medium and RPMI medium with $10 \%$ FBS were slightly larger than particles dissolved in water. DLS results for particle size in solution indicated that the PtNPs tended to form agglomerates in RPMI medium without serum compared to with serum.

Visualization by TEM showed spherical, cubic, rectangular, triangular, octahedral, and tetrahedral or truncated cubic, hexagonal, octahedral and tetrahedral particles with an average size of 25 (range, 5-50) nm (Figure 1E,F), which would favor high catalytic performance and efficiency.

\subsection{Effects of PtNPs on Cell Viability and Proliferation of THP-1 Cells}

The viability of THP-1 cells incubated with variously shaped PtNPs $(25-150 \mu \mathrm{g} / \mathrm{mL})$ for $24 \mathrm{~h}$ decreased dose-dependently with increasing concentrations of PtNPs. We then calculated the half-maximal inhibitory concentration ( $\mathrm{IC}_{50}$ ) of PtNPs for THP-1 cells before analyzing transcriptomic and molecular pathways. Increasing PtNP concentrations corresponded to decreasing cellular metabolic activity (Figure 2A). The cells lost 10\% and $90 \%$ of their viability when incubated with the minimal $(25 \mu \mathrm{g} / \mathrm{mL})$ and maximal $(150 \mu \mathrm{g} / \mathrm{mL})$ concentrations of PtNPs, compared with untreated cells that were $100 \%$ viable. The viability of THP- 1 cells incubated with $25,50,75,100,125$, and $150 \mu \mathrm{g} / \mathrm{mL}$ PtNPs was significantly decreased to $10 \%, 30 \%, 50 \%, 70 \%, 80 \%$, and $90 \%$ respectively. The trend of THP-1 cell proliferation similarly decreased with increasing concentrations of PtNPs (Figure 2B). The $\mathrm{IC}_{50}$ of PtNPs against THP-1 cells was $75 \mu \mathrm{g} / \mathrm{mL}$. Bendale et al. [15] reported that PtNPs exert cytotoxic effects on cancer cell lines, but not on normal cells, even at the highest dose tested. Increasing the ICR-191 concentration corresponded to decreasing cellular metabolic activity in non-cancerous HaCaT and cancerous MelJuSo cells incubated with PtNPs. In addition, ICR-191 has a more powerful impact on $\mathrm{HaCaT}$ than on MelJuSo cells [40]. PtNPs were established as having anticancer and cytotoxic activities against various type of cancerous and non-cancerous cells ha. For instance, PtNPs penetrate cells via diffusion or endocytosis and then form intracellular aggregates [5,41-43]. Platinum NPs inhibit HeLa cell viability and proliferation by activating p53 [41] and inhibiting U87, U118, and U251 glioblastoma tumor cell proliferation [41,44,45]. Cytotoxicity is dependent on PtNP size in Raw 264.7 cells incubated with various concentrations of PtNPs [46]. The present findings together with published data indicate that PtNPs would be excellent tools with which to analyze transcriptomic and molecular pathways. 
A

120

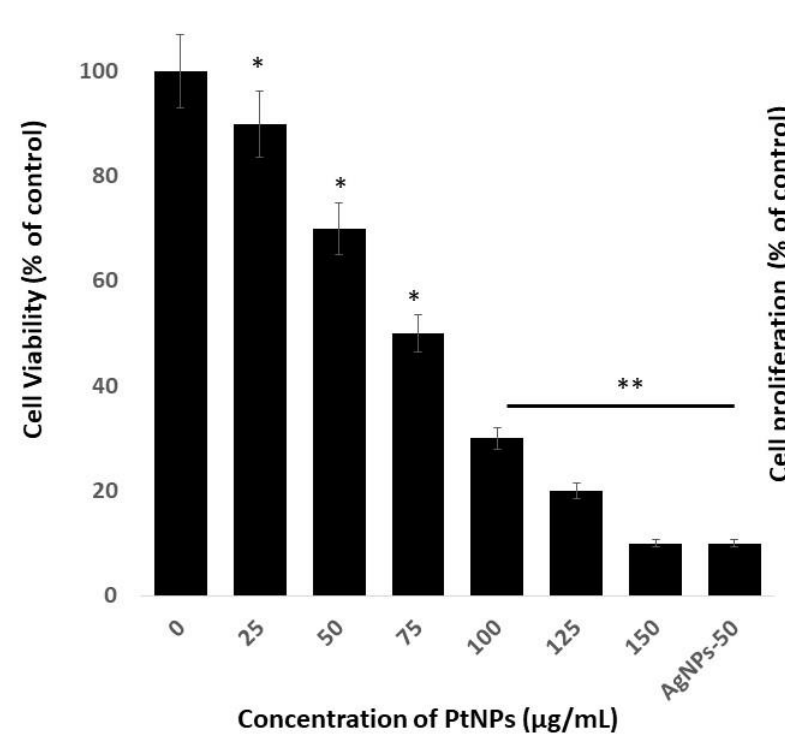

B

120

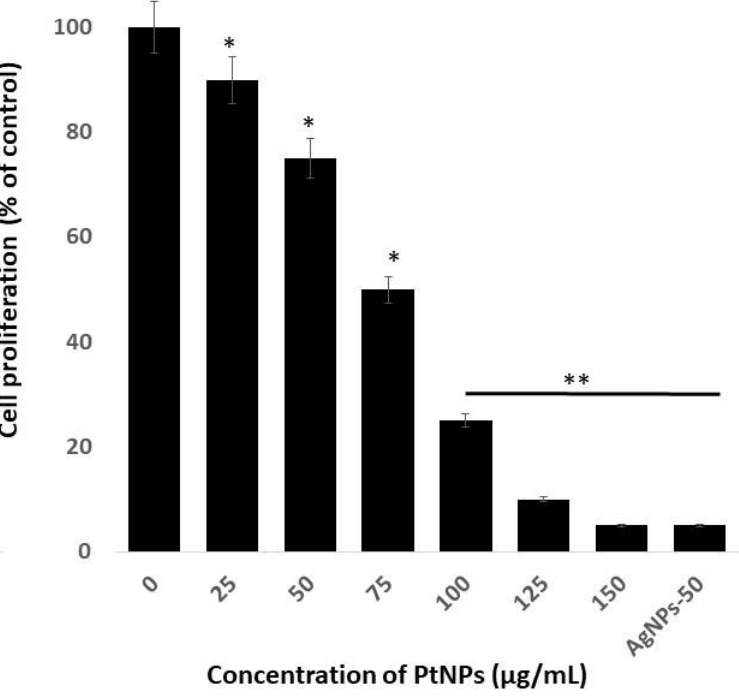

Figure 2. Effect of PtNPs on cell viability and proliferation of THP-1 cells. (A) Viability of THP-1 cells was determined after $24 \mathrm{~h}$ of exposure to different concentrations of PtNPs $(25-150 \mu \mathrm{g} / \mathrm{mL})$. (B) Proliferation of THP-1 cells was determined using the 5-bromo-2'-deoxyuridine (BrdU) assay after $24 \mathrm{~h}$ of exposure to different concentrations of PtNPs $(25-150 \mu \mathrm{g} / \mathrm{mL})$. The treated groups showed statistically significant differences from the control group by the Student's $t$-test $\left({ }^{*} p<0.05\right)$. * significant; ** highly significant.

\subsection{Morphology of THP-1 Cells in the Presence of PtNPs}

Morphological changes comprise the hallmark of apoptosis. We assessed the effects of PtNPs on THP-1 cells to determine correlations between altered cell morphology and cell viability, as well as proliferation. The cells were incubated with PtNPs $(25-150 \mu \mathrm{g} / \mathrm{mL})$ for $24 \mathrm{~h}$ at the monocytic stage. Phase contrast microscopy revealed significant differences between control THP-1 macrophages and THP-1 cells incubated with PtNPs (Figure 3). The morphology of the cells incubated with various concentrations of PtNPs significantly changed, with loss of uniformity and remarkable shrinkage around cell clusters. Increasing PtNP concentrations caused remarkable changes in cell morphology such as extreme shrinkage, membrane blebbing, and loss of plasma membrane integrity. These results were consistent with those of cell viability, cell proliferation, and lactate dehydrogenase (LDH) and intracellular protease leakage. Digital microscopy data suggested that PtNPs are cytotoxic. Kutwin et al. [44] reported that the morphology of U87 glioblastoma cells incubated with various concentrations of PtNPs was characteristic of cell death with long branched protrusions and shrinkage. Collectively, PtNPs induced morphological changes that eventually led to cell death. 



Figure 3. PtNPs altered the morphology of THP-1 cells. The effect of PtNPs on cell morphology was determined after $24 \mathrm{~h}$ of exposure to different concentrations of PtNPs $(25-150 \mu \mathrm{g} / \mathrm{mL})$ using an optical microscope. At least three independent experiments were performed for each sample. Scale bar, $200 \mu \mathrm{m}$.

\subsection{PtNPs Induce Cytotoxicity in THP-1 Cells}

Platinum nanoparticles were significantly cytotoxic to THP-1 cells. Cytotoxicity induces cell death upon membrane disruption that leads to release of the cytosolic enzyme lactate dehydrogenase (LDH) into the extracellular medium. We found more LDH in the medium of cells incubated with PtNPs than in controls, indicating that NPs lyse cells [22]. Figure 4A shows more LDH leakage at $75-150 \mu \mathrm{g} / \mathrm{mL}$ PtNPs, indicating a significant decrease in cell viability and a significant increase in LDH release. These findings indicated that the decreased cell viability and damage caused by the NPs ultimately caused the death of the cells [47]. Others also reported that PtNPs induce cytotoxicity through LDH leakage in cancer cells including A549 lung carcinoma, LNCaP prostate cancer, and OS epithelial (U2OS) cells $[17,18,47]$.

We assessed associations between intracellular proteases and a luminogenic peptide substrate in membrane integrity assays to further confirm the cytotoxic nature of medium-sized, anisotropic PtNPs in THP-1 cells. The results were in agreement with those of the LDH assays; increasing concentrations of PtNPs increased intracellular protease leakage via membrane damage (Figure 4B). The LDH leakage and intracellular protease caused more membrane damage and, consequently, more LDH enzyme and protease in the medium with respect to corresponding PtNP concentrations. 
A

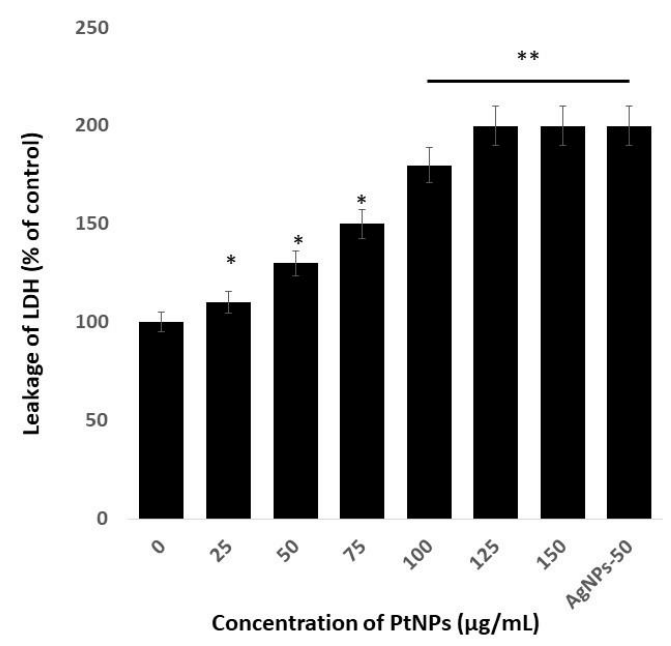

B

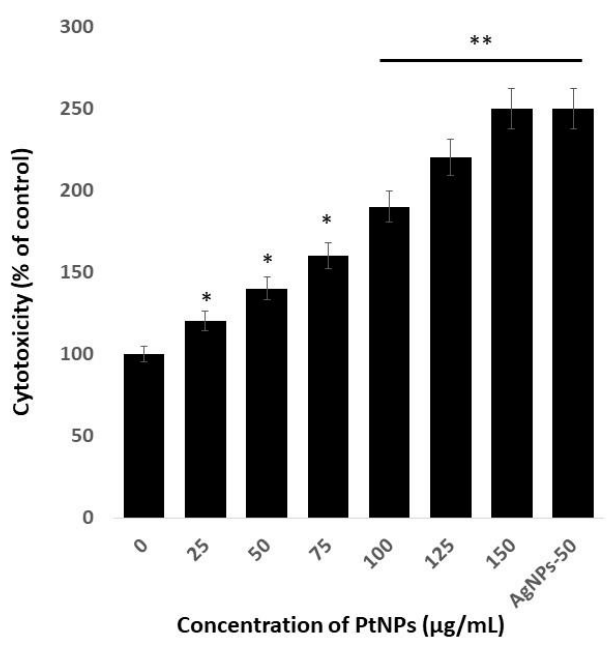

Figure 4. PtNPs increase the leakage of lactate dehydrogenase (LDH) and intracellular protease. (A) THP-1 cells were treated with PtNPs $(25-150 \mu \mathrm{g} / \mathrm{mL})$ for $24 \mathrm{~h}$, and LDH activity was measured at $490 \mathrm{~nm}$ using the LDH cytotoxicity kit. (B) Intracellular protease activity was determined by assessing the association of intracellular proteases with a luminogenic peptide substrate (alanyl-alanylphenylalanyl-aminoluciferin) after $24 \mathrm{~h}$ of exposure to PtNPs $(25-150 \mu \mathrm{g} / \mathrm{mL})$. Cell death was quantified as the ratio of living cells. At least three independent experiments were performed for each sample. Results are expressed as mean fold change \pm standard deviation from three independent experiments. The treated groups showed statistically significant differences from the control group by the Student's $t$-test $\left({ }^{*} p<0.05 ;{ }^{* *} p<0.01\right)$.

* significant; ${ }^{* *}$ highly significant.

\subsection{Platinum-Based NPs Induce ROS, Lipid peroxidation (LPO), Nitric Oxide (NO), and Protein Carbonylation in THP-1 Cells}

The link between oxidative stress and the redox balance plays critical roles in the cellular and tissue functions of cells and tissues and their impairment leads to various diseases. Macromolecular oxidation in response to ROS is associated with impaired cellular functions. Reactive nitrogen species (RNS) elicit various modifications of macromolecules and lead to nitro-oxidative stress. We investigated oxidative, lipoperoxidation, nitro-oxidative stress, and protein carbonylation in THP-1 cells incubated with various concentrations of PtNPs for $24 \mathrm{~h}$. Figure 5A shows that PtNPs dose-dependently induced intracellular ROS production, with the response being substantial at $75 \mu \mathrm{g} / \mathrm{mL}$. Platinum NPs induce ROS generation by impairing receptor activator of nuclear factor $\mathrm{kB}$ ligand (RANKL) signaling [48]. For instance, incubating HepG2 cells with 68-nm PtNPs suggested that ROS are dose-dependently induced [34]. Ultra-small PtNPs also induce ROS generation in THP-1 cells [22]. The increased amount of intracellular ROS due to PtNPs could affect the integrity of cell components. Altogether, our findings suggested that ROS production is a common mechanism of toxicity In Vitro and In Vivo.

That PtNPs induced oxidative stress with lipid peroxidation was confirmed by the dose-dependent increase in malondialdehyde (MDA) in THP-1 cells incubated with PtNPs. The results showed a statistically significant increase in MDA with increasing doses of PtNPs $(p<0.05$; Figure 5B). Exposure to PtNPs might cause the production of ROS that subsequently increase MDA concentrations. An imbalanced redox potential might also be a cause of PtNP toxicity. Administering PtNPs induces intracellular oxidative stress via the generation of ROS that disrupt the antioxidant system [18,47]. An imbalance in antioxidant enzymes also causes lipid peroxidation [49], which deteriorates the cell membrane and renders it susceptible to further oxidation by free radicals [49,50]. Excess ROS production results in the oxidation of cell components such as proteins and lipids. Increased amounts of hydroxyl peroxyl radicals disrupt double bonds in fatty acids and generate highly reactive radicals, 
which in turn increase MDA production. We concluded that an increased amount of MDA might disintegrate the cellular assembly by altering proteins, carbohydrates, and nucleic acid bases.
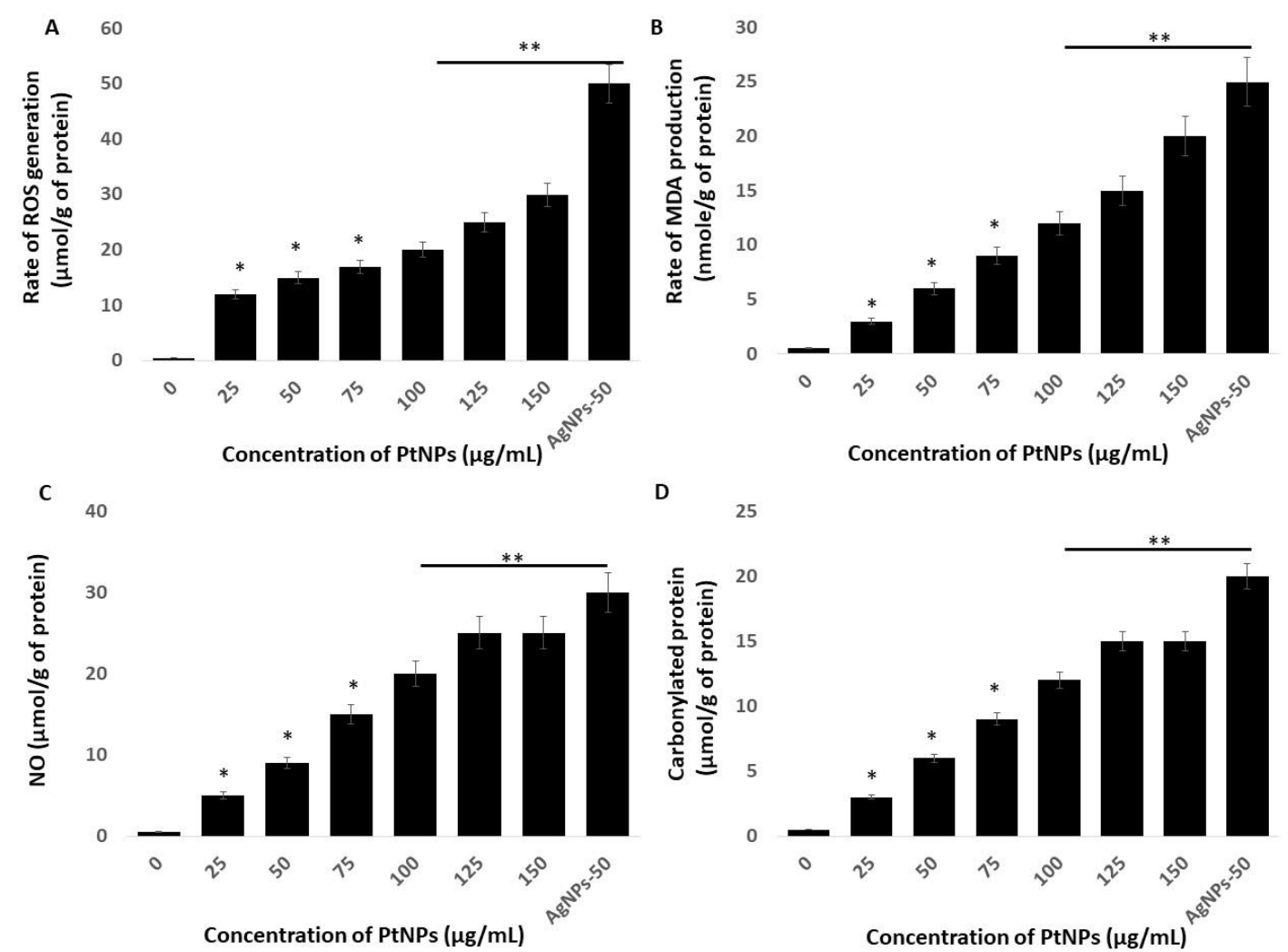

Figure 5. PtNPs increase generation of reactive oxygen species (ROS), lipid peroxidation, nitric oxide (NO), and protein carbonylation (A) THP-1 cells were treated with PtNPs (25-150 $\mu \mathrm{g} / \mathrm{mL})$ for $24 \mathrm{~h}$. Spectrophotometric analysis of ROS using DCFH-DA. (B) Malondialdehyde (MDA) concentration was measured using a thiobarbituric acid-reactive substances assay and is expressed as nanomoles per gram of protein. (C) NO production was quantified spectrophotometrically using the Griess reagent and is expressed as micromoles per gram of protein (D). Protein carbonylation content was determined and is expressed as micromoles per gram of protein. The results are expressed as means \pm standard deviation of three independent experiments. The treated groups showed statistically significant differences from the control group by the Student's $t$-test $\left({ }^{*} p<0.05 ;{ }^{* *} p<0.01\right) .{ }^{*}$ significant; ${ }^{* *}$ highly significant.

We investigated the role of NO in the PtNP-induced cytotoxicity of THP-1 cells. We found that incubating THP- 1 cells with $25-150 \mu \mathrm{g} / \mathrm{mL}$ PtNPs for $24 \mathrm{~h}$ caused a concentration-dependent increase in NO (Figure 5C). The amounts of NO were 5 and $\sim 25 \mu \mathrm{M}$ in cells incubated with 25 and $150 \mu \mathrm{g} / \mathrm{mL}$ PtNPs compared with $0.5 \mu \mathrm{M}$ of NO in untreated cells. The amount of NO was significantly augmented in THP-1 cells incubated with 25, 50, 75, 100, 125, and $150 \mu \mathrm{g} / \mathrm{mL}$ PtNPs to 5, 9, 15, 20, and $25 \mu \mathrm{M}$ respectively. Silver NPs induce NO in various types of cancer cells including human pancreatic ductal adenocarcinoma and human alveolar basal epithelial cells [39,51]. Platinum NPs similarly induce NO in cancerous cells such as THP- 1 and human prostate cancer cells $[17,22]$. The abnormal generation of NO increases nitro-oxidative stress and upregulation of the cell-death mediator p53 [52]. Collectively, PtNPs dose-dependently induce NO that is responsible for cell death induced by nitro-oxidative stress.

Oxidative stress is the result of an imbalance between ROS generation and detoxification, and protein carbonyl levels might become enhanced as a consequence. Thus, how biological systems respond to oxidative stress induced by NP can be determined by measuring protein carbonylation, which is a biomarker of oxidation. Hence, we estimated protein carbonylation in THP- 1 cells incubated with $25-150 \mu \mathrm{g} / \mathrm{mL}$ PtNPs for $24 \mathrm{~h}$ and found a dose-dependent increase in carbonylated proteins (Figure 5D). The amounts of protein carbonylation were 3 and $\sim 15 \mu \mathrm{M}$ in cells incubated with 25 and 
$150 \mu \mathrm{g} / \mathrm{mL}$ PtNPs, respectively, whereas that in untreated cells was $0.5 \mu \mathrm{M}$. Protein carbonylation was significantly increased to 3, 6, 9, 12, and $15 \mu \mathrm{M}$ in THP-1 cells incubated with 25, 50, 75, 100, 125, and $150 \mu \mathrm{g} / \mathrm{mL}$ PtNPs, respectively. Silver NPs induce protein carbonylation in Daphnia magna [53], as well as in THP-1 macrophages, primary neuronal cells, and human colon epithelial cells in a particle size-dependent manner [54-56]. Carbonylation is irreversible; it causes a loss of protein function that is often associated with protein unfolding and aggregation, and it is involved in signal transduction [57]. Oxidatively modified proteins are involved in glucose metabolism, mitochondrial function, cellular motility/structural integrity, and protein degradation [58]. Elevated protein carbonylation causes various type of pathologies including metabolic [59], neurodegenerative [60] aging, and age-related diseases [61,62]. Collectively, these findings suggest that oxidative stress is a common mechanism of PtNP-induced toxicity in THP-1 cells through increasing intracellular amounts of ROS, MDA, NO, and protein carbonylation.

\subsection{Platinum NPs Impair Antioxidants in THP-1 Cells}

Incubating cells with nanoparticles causes an imbalance of antioxidants in a cellular oxidative state by increasing ROS and decreasing antioxidants. Reduced glutathione (GSH) is an important intracellular antioxidant that plays vital roles in protecting cells against oxidative stress [63]. The amount of GSH decreases in cells under oxidative stress due to its oxidation to glutathione disulfide (GSSG). The amount of GSH was significantly reduced at all tested PtNPs concentrations (Figure 6A). Concentrations of intracellular GSH significantly decreased from 90 to $20 \mu \mathrm{M}$ in THP-1 cells incubated with 25 and $150 \mu \mathrm{g} / \mathrm{mL}$ PtNPs, respectively, compared with the $100 \mu \mathrm{M}$ in untreated cells. The amount of GSH was significantly decreased to $90,80,70,50$, and $20 \mu \mathrm{M}$, respectively, in THP-1 cells incubated with 25, 50, 75, 100, 125, and $150 \mu \mathrm{g} / \mathrm{mL}$ PtNPs. These findings agreed with those of previous studies showing decreased GSH concentrations in HT29, A549 lung carcinoma, osteosarcoma, prostate cancer, and THP-1 cells incubated with PtNPs [17,22,27,47].

Thioredoxin (TRX) is a small 12-kDa protein with essential functions as an active oxidoreductase and an electron donor of peroxiredoxins that are important for peroxide reduction [64]. Hence, we evaluated the amounts of TRX in THP-1 cells incubated with PtNPs for $24 \mathrm{~h}$ and found a significant reduction in TRX at all tested concentrations of PtNPs (Figure 6B). Increasing concentrations of PtNPs induced a significant decrease in TRX. The amounts of TRX were 70 and $\sim 20 \mu \mathrm{M}$ in cells incubated with 25 and $150 \mu \mathrm{g} / \mathrm{mL}$ PtNPs, respectively, compared with $80 \mu \mathrm{M}$ in untreated cells. The amounts of TRX were significantly decreased to $80,70,60,50,40,30$, and $20 \mu \mathrm{M}$, respectively, in THP-1 cells incubated with $25,50,75,100,125$, and $150 \mu \mathrm{g} / \mathrm{mL}$ PtNPs. Thioredoxin regulates various cellular functions in response to redox signals and stress, and modulates various signaling pathways, transcription factors, and immunological responses [65]. It minimizes damage to vital organelles such as mitochondria and nuclei via ROS leakage during mitochondrial respiration [66]. Furthermore, cytosolic TRX plays important roles in the control of growth, apoptosis, and chronic inflammation [67]. Overall, PtNPs can play critical roles in decreasing intracellular concentrations of TRX, which is essential for many cellular functions.

We measured superoxide dismutase (SOD) protein in THP-1 cells incubated for $24 \mathrm{~h}$ with PtNPs and found a statistically significant decrease in SOD as the PtNP concentrations increased (Figure 6C). The level of SOD was 20 and $\sim 6 \mu \mathrm{M}$ in cells incubated with minimal $(25 \mu \mathrm{g} / \mathrm{mL})$ and maximal $(150 \mu \mathrm{g} / \mathrm{mL})$ concentrations of PtNPs compared with $20 \mu \mathrm{M}$ in untreated cells. The amounts of SOD in THP-1 cells incubated with 25, 50, 75, 100, 125, and $150 \mu \mathrm{g} / \mathrm{mL}$ PtNPs were significantly decreased to 20,18,15,12, 9, and $6 \mu \mathrm{M}$, respectively. Metal NPs such as AgNPs induce ROS and reactive nitrogen species (RNS) in PANC-1 cells in association with significantly disturbed antioxidant enzymes at the protein and messenger RNA (mRNA) levels. The production of ROS and/or RNS along with an impaired antioxidant system led to the programmed death of cancer cells [68]. Zinc oxide NPs (ZnONPs) significantly decrease antioxidant concentrations in hepatoma cells and trigger apoptosis [69]. A reduced amount of SOD leads to the apoptosis of human skin carcinoma and human 
fibrosarcoma cells incubated with $20 \mathrm{~nm}$ AgNPs [70,71], and amounts of SOD1 protein and mRNA are reduced in PANC-1 cells incubated with metal nanoparticles [51].
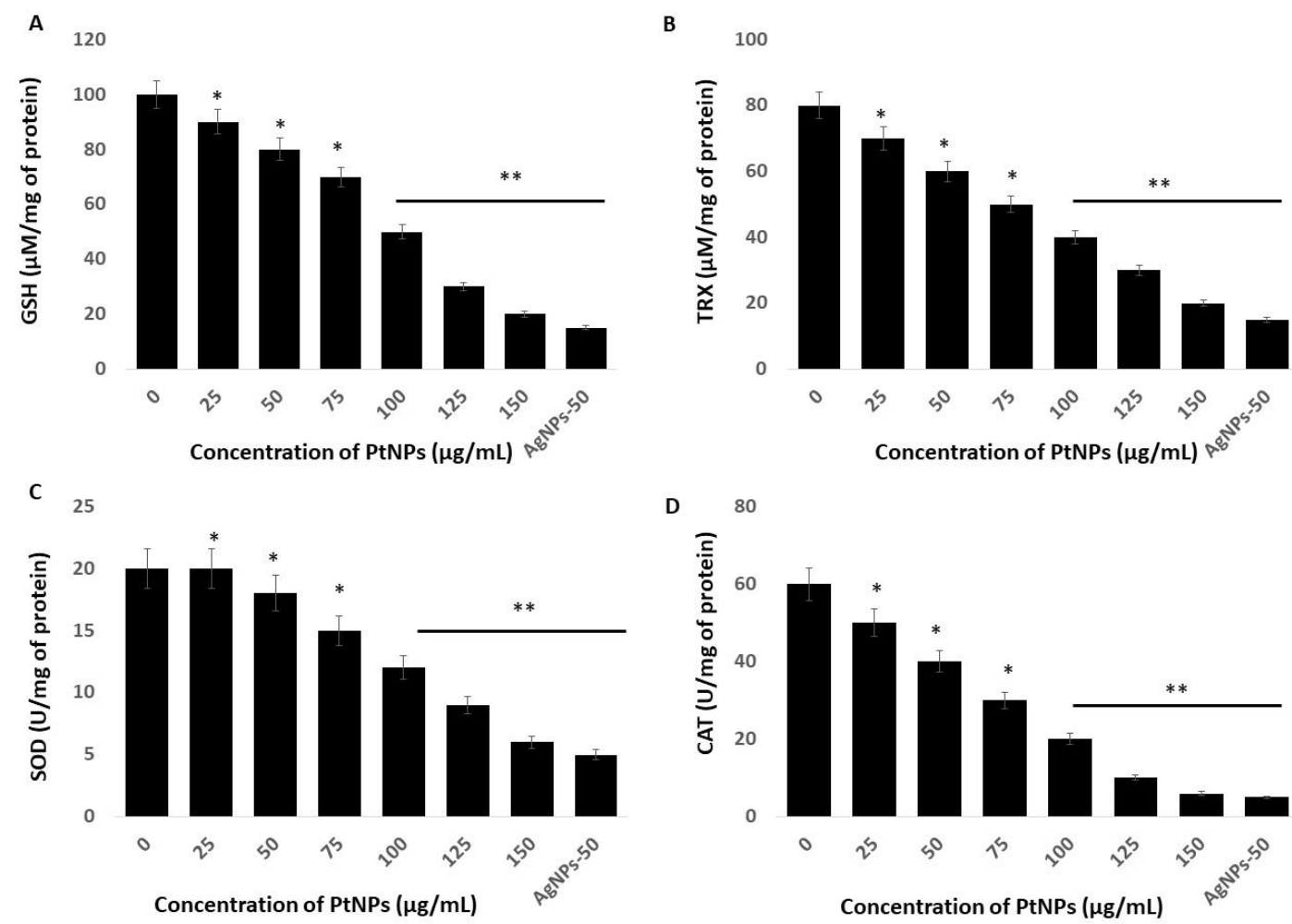

Figure 6. Effect of PtNPs on antioxidant markers. THP-1 cells were treated with different concentrations of PtNPs $(25-150 \mu \mathrm{g} / \mathrm{mL})$ for $24 \mathrm{~h}$. After incubation, the cells were harvested and washed twice with ice-cold phosphate-buffered saline solution. The cells were collected and disrupted by ultrasonication for $5 \mathrm{~min}$ on ice. (A) Glutathione (GSH) concentration is expressed as $\mu \mathrm{M}$ per mg of protein. (B) Thioredoxin (TRX) concentration is expressed as $\mu \mathrm{M}$ per mg of protein. (C) Superoxide dismutase (SOD) is expressed as units per mg of protein. (D) Catalase (CAT) is expressed as units per mg of protein. Results are expressed as mean fold change \pm standard deviation from three independent experiments. he treated groups showed statistically significant differences from the control group by the Student's $t$-test $\left({ }^{*} p<0.05 ;{ }^{* *} p<0.01\right)$. * significant; ${ }^{* *}$ highly significant.

Others showed that PtNPs can interfere with cellular functions, cause toxic effects, and might interfere with specific biological systems [22,47]. Toxicity induced by PtNPs is the result of ROS generation, glutathione depletion, and alterations in the amounts of intracellular superoxide dismutase (SOD) and in catalase (CAT) enzyme activities. Catalase is a crucial antioxidant enzyme that plays a critical role in maintaining the intracellular redox balance. We measured CAT in THP-1 cells incubated with PtNPs. We found a statistically significant decrease in CAT after incubation with increasing PtNP concentrations (Figure 6D). The levels of CAT were 50 and $\sim 6 \mu \mathrm{M}$ in cells incubated with minimal $(25 \mu \mathrm{g} / \mathrm{mL})$ and maximal $(150 \mu \mathrm{g} / \mathrm{mL})$ concentrations of PtNPs, respectively, compared with $60 \mu \mathrm{M}$ in untreated cells. The amount of CAT was significantly decreased to 50, 40, 30, 20, 10, and $6 \mu \mathrm{M}$, respectively, in THP-1 cells incubated with 25, 50, 75, 100, 125, and $150 \mu \mathrm{g} / \mathrm{mL} \mathrm{PtNPs.}$ Intracellular oxygen reduced to water through electron transport chains protects cells from normal ROS damage caused by catalase. A decreased amount of catalase cannot overcome damage caused by oxidative stress. 
2.7. PtNPs Cause Mitochondrial Dysfunction, and Decrease ATP Content, Mitochondrial Copy Number, and Peroxisome Proliferator-Activated Receptor Gamma Coactivator 1-Alpha (PGC-1 Alpha) Expression

Mitochondria are the powerhouses of cells and crucial to the regulation of important functions such as ROS production and scavenging, ATP production, intracellular regulation of $\mathrm{Ca}^{2+}$ and apoptotic cell death, and activation of the caspase family of proteases [72]. Therefore, studies of the effects of PtNPs on mitochondrial dysfunction are essential. We investigated the integrity of the mitochondrial membrane by incubating THP-1 cells with various concentrations of PtNPs for $24 \mathrm{~h}$ and then measuring aggregate-to-monomer ratios. The intracellular amounts of monomers and the aggregate ratio significantly decreased with increasing concentrations of PtNPs (Figure 7A). The aggregate/monomer ratio was $90 \%$ and $\sim 10 \%$ in cells incubated with minimal $(25 \mu \mathrm{g} / \mathrm{mL})$ and maximal $(150 \mu \mathrm{g} / \mathrm{mL})$ concentrations of PtNPs, respectively, compared with $100 \%$ in untreated cells. The aggregate-to-monomer ratios were significantly decreased to $90 \%, 80 \%, 60 \%, 40 \%, 20 \%$, and $10 \%$, respectively, in THP-1 cells incubated with 25, 50, 75, 100, 125, and $150 \mu \mathrm{g} / \mathrm{mL}$ PtNPs. Changes in mitochondrial membrane potentials indicate mitochondrial dysfunction, which ultimately decreases ATP production [73]. Others also suggested that PtNPs cause mitochondrial dysfunction in human embryonic kidney (HEK293) [74], THP-1 [22], prostate cancer [17], and osteosarcoma [18] cells through changing the membrane potential. Mitochondrial dysfunction induces apoptotic cell death through the loss of mitochondrial membrane potential (MMP), and increased expression of the Bcl-2 family of proteins promotes the release of cytochrome c, a major effector of apoptosis, which, together with the loss of MMP, causes early events in some apoptotic processes [75-77].
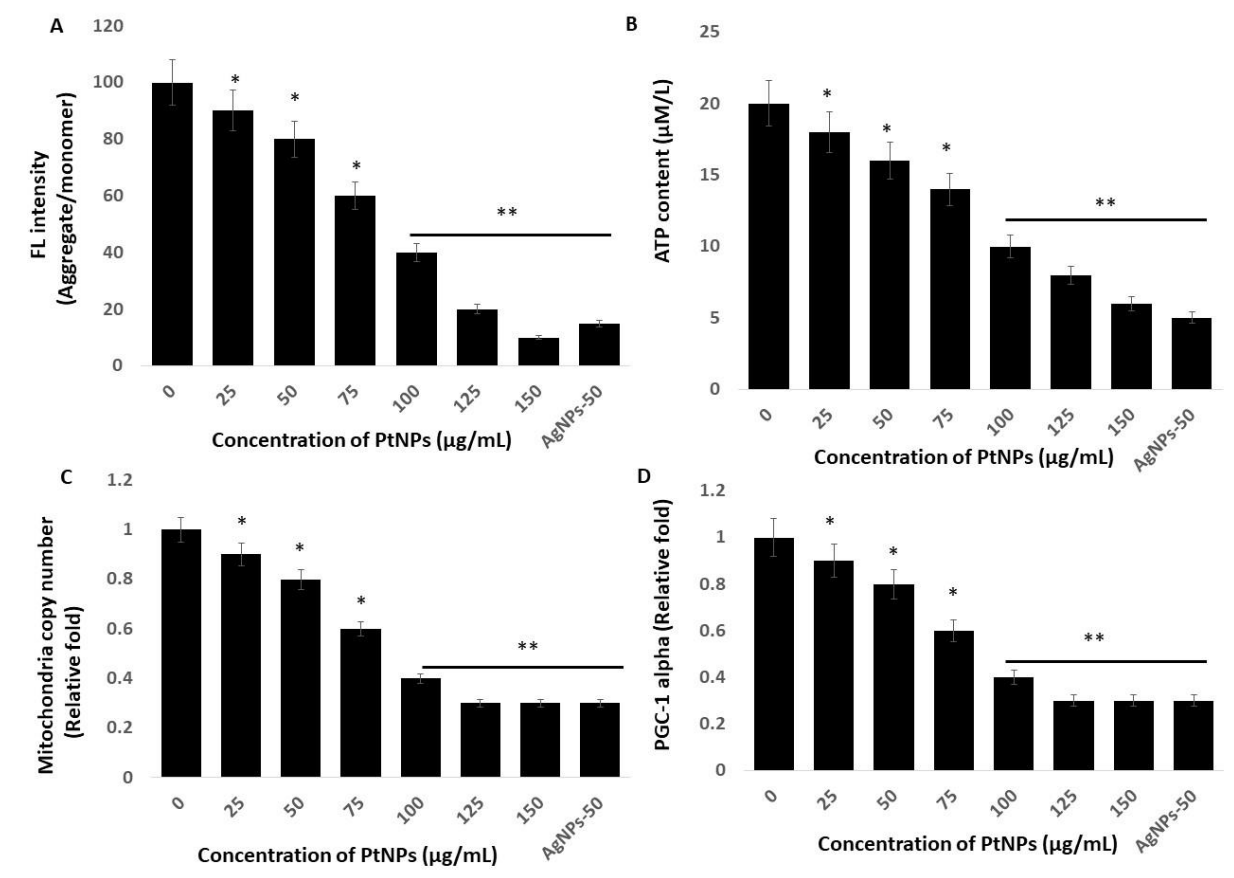

Figure 7. PtNPs decreased mitochondrial membrane potential (MMP), ATP content, mitochondrial copy number, and Peroxisome proliferator-activated receptor gamma coactivator 1-alpha (PGC-1 Alpha) PGC1 $\alpha$ expression. (A) THP-1 cells were treated with PtNPs $(25-150 \mu \mathrm{g} / \mathrm{mL})$ for $24 \mathrm{~h}$, and MMP was determined using the cationic fluorescent indicator cationic carbocyanine dye (JC-1). (B) THP-1 cells were treated with PtNPs (25-150 $\mu \mathrm{g} / \mathrm{mL})$ for $24 \mathrm{~h}$, and the intracellular ATP content was determined according to the manufacturer's instructions (Sigma-Aldrich, St. Louis, MO, USA; Catalog Number MAK135). (C). Mitochondrial copy number was determined via RT-PCR. (D). Expression of PGC1 $\alpha$ was determined via RT-PCR. Results are expressed as mean fold change \pm standard deviation from three independent experiments. The treated groups showed statistically significant differences from the control group by the Student's $t$-test $\left({ }^{*} p<0.05 ;{ }^{* *} p<0.01\right) .{ }^{*}$ significant; ${ }^{* *}$ highly significant. 
We assessed the amount of ATP produced in THP-1 cells incubated with various concentrations of PtNPs for $24 \mathrm{~h}$, because ATP synthesis is dependent on the integrity of the mitochondrial membrane, which regulates hydrogen ion pumping across the inner membrane during electron transport and oxidative phosphorylation [78]. The results showed a statistically significant decrease in ATP production as the PtNPs concentration increased throughout the applied range (Figure 7B). The amount of ATP was 18 and $\sim 6 \mu \mathrm{M}$ in cells incubated with the minimal $(25 \mu \mathrm{g} / \mathrm{mL})$ and maximal $(150 \mu \mathrm{g} / \mathrm{mL})$ concentrations of PtNPs compared with $20 \mu \mathrm{M}$ in untreated cells. Amounts of ATP were significantly decreased to 18 , $16,14,10,8$, and $6 \mu \mathrm{M}$, respectively, in THP-1 cells incubated with 25, 50, 75, 100, 125, and $150 \mu \mathrm{g} / \mathrm{mL}$ PtNPs. Platinum NPs might decrease the production of ATP in human THP-1 [22], prostate cancer [17], and osteosarcoma [18] cells. Excessive ROS generation impairs mitochondrial functions in terms of diminished oxidative capacity and antioxidant defense, reduced oxidative phosphorylation (OXPHOS), and decreased ATP production [79], and it damages mitochondrial proteins/enzymes, membranes, and DNA, collectively leading to the interruption of ATP generation and other essential mitochondrial functions [80]. Overall, PtNPs play an important role in ATP production.

An imbalance between pro-oxidants and antioxidants causes oxidative damage to mitochondrial proteins, DNA, and lipids [81], which impairs enzyme functions in the respiratory chain and ultimately leads to mitochondrial dysfunction and reduced mitochondrial biogenesis [82]. Reduced numbers of mitochondria and a diminished capacity for oxidative phosphorylation results in impaired mitochondrial biogenesis $[83,84]$. Hence, we determined the copy number of mitochondria using RT-PCR and found that it significantly decreased in THP-1 cells incubated with increasing PtNP concentrations over the entire range of applied concentrations. (Figure $7 \mathrm{C}$ ). The relative ratio of copy numbers was decreased 0.9 - and $\sim 0.3$-fold in cells incubated with the minimal $(25 \mu \mathrm{g} / \mathrm{mL})$ and maximal $(150 \mu \mathrm{g} / \mathrm{mL})$ concentrations of PtNPs, respectively, compared with control. The fold copy number was significantly decreased 0.9-, 0.8-, 0.6-, 0.4-, 0.3-, and 0.3-fold, respectively, in THP-1 cells incubated with $25,50,75,100,125$, and $150 \mu \mathrm{g} / \mathrm{mL}$ PtNPs.

Mitochondrial biogenesis is controlled by several transcription factors that are important to maintain the number and size of mitochondria, as well as nuclear and mitochondrial genomes. Among several transcription factors, peroxisome proliferator-activated receptor (PPAR)- $\gamma$ coactivator- $1 \alpha$ (PGC- $1 \alpha$ ) plays a critical role in biogenesis. Therefore, we evaluated PGC- $1 \alpha$ expression in THP- 1 cells incubated with PtNPs for $24 \mathrm{~h}$. The expression of PGC- $1 \alpha$ was significantly and dose-dependently decreased by increasing concentrations of PtNPs (Figure 7D). The relative decrease was 0.9- and $\sim 0.3$-fold in cells incubated with the minimal $(25 \mu \mathrm{g} / \mathrm{mL})$ and maximal $(150 \mu \mathrm{g} / \mathrm{mL})$ concentration of PtNPs compared with control. The fold copy number was significantly decreased to 0.9-, 0.8-, 0.6-, 0.4-, 0.3-, and 0.3-fold, respectively, in THP-1 cells incubated with 25, 50, 75, 100, 125, and $150 \mu \mathrm{g} / \mathrm{mL}$ PtNPs, and this was associated with mitochondrial copy numbers. Therefore, THP-1 cells incubated with PtNPs were associated with defective mitochondrial biogenesis manifested by impaired mitochondrial dysfunction, reduced ATP generation, low copy numbers, and decreased mitochondrial gene expression.

\subsection{PtNPs Induce Cell Death Mediated by Endoplasmic Reticulum Stress}

The endoplasmic reticulum (ER) regulates various cellular functions including the synthesis and post-translational modifications of secretory, luminal, and transmembrane proteins, protein folding, and the maturation of secretory and membrane proteins synthesized de novo [85]. Various external factors including NP, can trigger endoplasmic reticulum stress (ERS) which can result in aberrant protein folding. The unfolded protein response (UPR) is a is a component of the ER adaptive system that is highly conserved in most eukaryotes. The UPR comprises the principal signaling pathways that involve inositol-requiring enzyme 1 (IRE1), (PERK), and ATF6 [86]. All these genes play critical roles in the UPR adaptive system. We quantified the expression of the established ERS markers IRE1, PERK, ATF6, and ATF4, to determine the effects of PtNPs on ERS in THP-1 cells incubated with various concentrations of PtNPs for $24 \mathrm{~h}$. Platinum NPs obviously induced all of these stress markers 
at all applied concentrations (Figure 8). These data showed that PtNPs cause ERS and associated UPR induction in THP-1 cells. Christen et al. [87] reported that silica NPs induce ERS through the activation of ATF-4, BiP, and X-box binding protein 1 (XBP-1s) in Huh7 cells. The IRE1 gene induces apoptosis by activating apoptosis signaling kinase 1 (ASK1) and interacting with tumor necrosis factor receptor-associated factor (TRAF)2. Excessive and prolonged ER stress ultimately causes apoptosis by promoting the expression of CCAAT/enhancer-binding protein homologous protein (CHOP) [88-90]. Sustained and long-term ERS accelerates oxidative stress [90], which in turn accelerates ERS and activates apoptotic signaling pathways [91,92]. Overall, PtNPs induced ERS-mediated cell death through the expression of UPR genes responsible for adaptation in THP-1 cells.
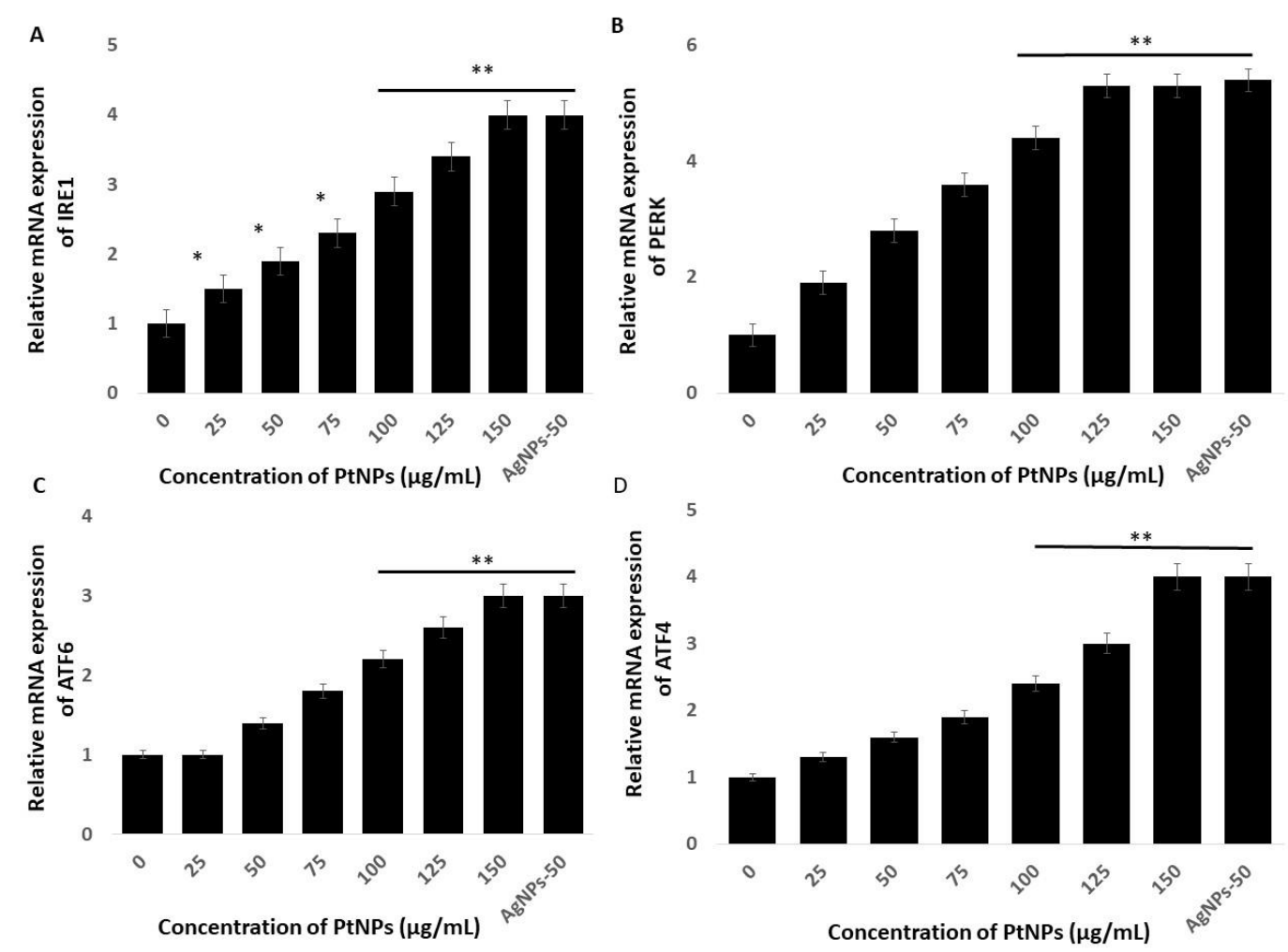

Figure 8. PtNPs enhance the expression of endoplasmic reticulum stress (ERS) genes. THP-1 cells were treated with various concentrations of PtNPs $(25-150 \mu \mathrm{g} / \mathrm{mL})$ for $24 \mathrm{~h}$. The messenger RNA (mRNA) expression of ERS genes (A) inositol-requiring enzyme 1 (IRE1), (B) PKR-like ER kinase (PERK), (C) activating transcription factor 6 (ATF6), and (D) ATF4 was analyzed using quantitative reverse-transcription polymerase chain reaction. After $24 \mathrm{~h}$, the fold change in the expression was determined relative to GAPDH expression. Results are expressed as mean fold change \pm standard deviation from three independent experiments. The treated groups showed statistically significant differences from the control group by the Student's $t$-test $\left({ }^{*} p<0.05 ;{ }^{* *} p<0.01\right) .{ }^{*}$ significant; ** highly significant.

\subsection{PtNPs Induce Expression of Pro-Apoptotic and Anti-Apoptotic Genes}

Cell fate depends on the balance between the extent/severity of ERS and the capacity of the ER to restore ER homeostasis through the UPR. Stress to the ER induces apoptosis via major extrinsic and intrinsic pathways [93]. Mitochondrial dysfunction might play critical roles in ERS and activate genes associated with apoptosis, such as the Bcl-2 family in particular. On the other hand, ER stress activates p53, which induces apoptosis [94-96]. Stress to the ER activates many genes involved in the control of cell fate, including anti-apoptotic and pro-apoptotic genes such as Bax and Bcl-2 [97,98]. Hence, understanding the roles and mechanisms of cell apoptosis induced by ERS in THP- 1 cells incubated with PtNPs might provide important insights into how PtNPs induce cell death mediated 
by ER stress. Therefore, we evaluated expression of the important pro-apoptotic genes p53, Bax, Bcl-2, and caspase- 3 in THP-1 cells incubated with various concentrations of PtNPs for $24 \mathrm{~h}$. The results showed that PtNPs significantly activated these genes up to five-fold, and significantly downregulated Bcl-2 (Figure 9). The balance between anti- and pro-apoptotic proteins is important for maintaining normal mitochondrial function, as well as cell survival. The Bcl-2 family regulates ERS through physical interaction with ERS sensors and UPR components to induce apoptosis. Caspases also play crucial roles in ERS-mediated apoptosis. For instance, caspase-12 is activated during ERS, which sequentially activates caspase-7 and/or caspase-3, leading to mitochondria-independent apoptosis [99]. Our findings indicated that PtNPs respectively activate and downregulate pro- and anti-apoptotic genes, consequently leading to cell death. Collectively, ERS plays a critical role in PtNP-induced apoptosis that is mediated by mitochondria.
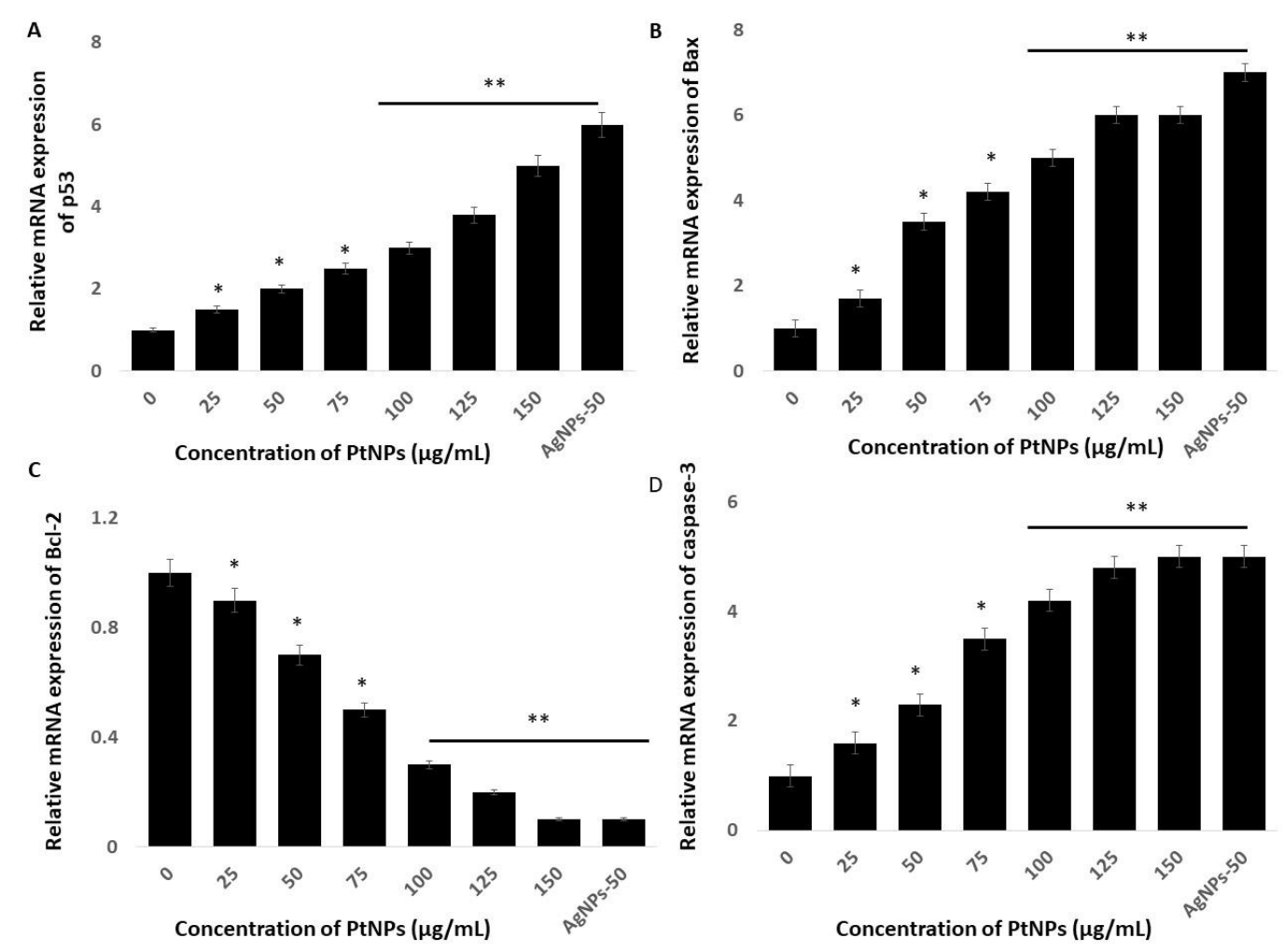

Figure 9. Effect of PtNPs on expression of pro- and anti-apoptotic genes. THP-1 cells were treated with various concentrations of PtNPs (25-150 $\mu \mathrm{g} / \mathrm{mL})$ for $24 \mathrm{~h}$. The mRNA expression of (A) p53, (B) Bax, (C) Bcl-2, and (D) caspase-3 genes was analyzed using quantitative reverse-transcription polymerase chain reaction in THP- 1 cells treated for $24 \mathrm{~h}$ with PtNPs. After $24 \mathrm{~h}$, the fold change in the expression was determined relative to GAPDH expression. All experiments were performed in triplicate, each being repeated at least three times. The treated groups showed statistically significant differences from the control group by the Student's $t$-test $\left({ }^{*} p<0.05 ;{ }^{* *} p<0.01\right) .{ }^{*}$ significant; ${ }^{* *}$ highly significant.

\subsection{PtNPs Induce Oxidative Damage to DNA}

Reactive oxygen species are highly reactive, and they can oxidize lipids, proteins, and nucleic acids. The incorporation of an oxidized base can result in oxidative damage to mitochondrial DNA (mtDNA) and nuclear DNA (nDNA). The most prominent and susceptible modified nucleobase adducts are 8-oxo-2'-deoxyguanosine (8-oxo-dG) and 8-oxoguanine (8-oxoG), the latter of which is the major oxidized base in nucleotide pools, and in polymerized DNA or RNA [100,101]. Quantifying these adducts in THP-1 cells incubated with PtNPs might provide critical insights into the role of PtNPs in oxidative damage to mtDNA and normal DNA. Hence, we measured the levels of 8-oxo-dG and 8-oxoG using ELISA in THP-1 cells incubated with PtNPs for $24 \mathrm{~h}$. Increasing concentrations 
of PtNPs induced more 8-oxo-dG and 8-oxoG accumulation, with the effect being more pronounced at higher concentrations (Figure 10). The concentrations of 8-oxo-dG that accumulated in cells incubated with minimal $(25 \mu \mathrm{g} / \mathrm{mL})$ and maximal $(150 \mu \mathrm{g} / \mathrm{mL})$ concentrations of PtNPs were 100 and $\sim 2000 \mathrm{~nm} / \mathrm{DNA}(\mu \mathrm{g} / \mu \mathrm{L})$, respectively, compared with controls. The accumulation of 8-oxo-dG was significantly increased to 100, 200, 400, 800, 1500, and $2000 \mathrm{~nm} / \mathrm{DNA}(\mu \mathrm{g} / \mu \mathrm{L})$, respectively, in THP-1 cells incubated with $25,50,75,100,125$, and $150 \mu \mathrm{g} / \mathrm{mL} \mathrm{PtNPs}$. Cells incubated with minimal $(25 \mu \mathrm{g} / \mathrm{mL})$ and maximal $(150 \mu \mathrm{g} / \mathrm{mL})$ concentrations of PtNPs accumulated 200 and $\sim 6000 \mathrm{~nm} / \mathrm{DNA}(\mu \mathrm{g} / \mu \mathrm{L})$ of 8-oxo-G, respectively, compared with controls. The accumulation of 8-oxo-G was significantly increased to 200, 400, 800, 1500, 3000, and $6000 \mathrm{~nm} / \mathrm{DNA}(\mu \mathrm{g} / \mu \mathrm{L})$, respectively, in THP-1 cells incubated with $25,50,75,100,125$, and $150 \mu \mathrm{g} / \mathrm{mL}$ PtNPs. Notably, significantly more 8-oxo-G than 8-oxo-dG accumulated, indicating that PtNPs target mitochondrial, rather than normal DNA. Zinc oxide NPs induce cellular morphological modifications, mitochondrial dysfunction, reduced SOD, depleted GSH, and oxidative DNA damage in human hepatocyte and embryonic kidney cells [102]. Silicon dioxide $\mathrm{NPs}\left(\mathrm{SiO}_{2} \mathrm{NPs}\right)$ concentration- and size-dependently increase intracellular ROS, damage DNA, and cause apoptosis in $\mathrm{HaCaT}$ cells, and these effects closely correlate with increased oxidative stress [103]. Titanium and silver NPs, as well as ultra-small PtNPs, cause oxidative DNA damage in Cos-1, TK6, human alveolar basal epithelial, and THP-1 cells [22,39,104]. Collectively, these findings correlate with mitochondrial dysfunction. A possible mechanism of 8-oxo-dG and 8-oxo-G accumulation is the overproduction of ROS and RNS that could alter the balance of oxidants and antioxidants that would cause oxidative and nitrative stress and contribute to damaging DNA and RNA.
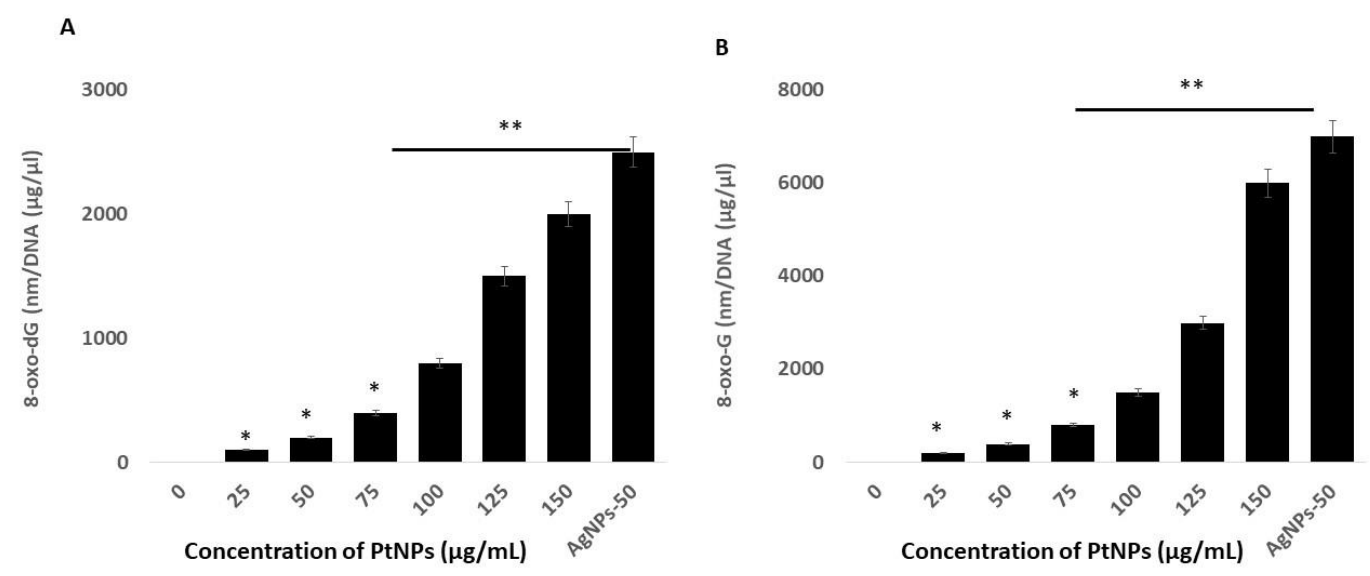

Figure 10. PtNPs increase oxidative damage to DNA and RNA. (A). THP-1 cells were treated with various concentrations of PtNPs $(25-150 \mu \mathrm{g} / \mathrm{mL})$ for $24 \mathrm{~h}$. The 8-oxo-2'-deoxyguanosine (8-oxo-dG) level was measured after $24 \mathrm{~h}$ of exposure. (B). THP-1 cells were treated with various concentrations of PtNPs (25-150 $\mu \mathrm{g} / \mathrm{mL})$ for $24 \mathrm{~h}$. The 8-oxoguanine (8-oxo-G) level was measured after $24 \mathrm{~h}$ of exposure. Results are expressed as means \pm standard deviation from three independent experiments. There was a significant difference between treated cells and untreated cells as per Student's $t$-test $\left({ }^{*} p<0.05\right)$. The treated groups showed statistically significant differences from the control group by the Student's $t$-test $\left({ }^{*} p<0.05 ;{ }^{* *} p<0.01\right) .{ }^{*}$ significant; ${ }^{* *}$ highly significant.

\subsection{PtNPs Activate Inflammatory Responses in THP-1 Cells}

Platinum NPs seem to play critical roles in oxidative stress, mitochondrial dysfunction, and ERS-mediated cell death. We examined whether these events are interconnected, and whether they could induce inflammatory responses in THP-1 cells incubated with PtNPs. The UPR and inflammation might be interconnected through ROS production, calcium release, nuclear factor kappa-light-chain-enhancer of activated B cells (NF-Kb) and mitogen-activated protein kinase (MAPK) activation, and induction of the acute-phase response [105]. To substantiate a relationship between ERS and inflammation, we evaluated levels of the critical cytokines, IL-1 $\beta$, IFN $\gamma$, TNF $\alpha$, and IL- 6 in 
THP-1 cells incubated with PtNPs for $24 \mathrm{~h}$. Each of these cytokines was significantly induced at all PtNP concentrations. Increasing concentrations of PtNPs significantly increased IL-1 $\beta$, IFN $\gamma, \mathrm{TNF} \alpha$, and IL-6 expression (Figure 11). The concentrations of IL- $1 \beta$ were 500 and $\sim 4000 \mathrm{pg} / \mathrm{mL} \mathrm{pg} / \mathrm{mL}$ in cells incubated with minimal $(25 \mu \mathrm{g} / \mathrm{mL})$ and maximal $(150 \mu \mathrm{g} / \mathrm{mL})$ concentrations of PtNPs compared with the control. Fold copy numbers were significantly increased to 500, 1000, 1500, 2000, 3000, and $4000 \mathrm{pg} / \mathrm{mL}$ respectively, in THP-1 cells incubated with 25, 50, 75, 100, 125, and $150 \mu \mathrm{g} / \mathrm{mL}$ PtNPs. The concentrations of IFN $\gamma$ were 800 and $\sim 6000 \mathrm{pg} / \mathrm{mL}$ in THP cells incubated with minimal $(25 \mu \mathrm{g} / \mathrm{mL})$ and maximal $(150 \mu \mathrm{g} / \mathrm{mL})$ concentrations of PtNPs compared with the control, and fold copy numbers were increased to 800, 1500, 2500, 3500,5000, and $6000 \mathrm{pg} / \mathrm{mL}$, respectively, when incubated with 25, $50,75,100,125$, and $150 \mu \mathrm{g} / \mathrm{mL}$ PtNPs. The concentrations of TNF $\alpha$ in cells incubated with minimal $(25 \mu \mathrm{g} / \mathrm{mL})$ and maximal $(150 \mu \mathrm{g} / \mathrm{mL})$ concentrations of PtNPs compared with the control were 1000 and $\sim 6000 \mathrm{pg} / \mathrm{mL}$, respectively, and the fold copy number was significantly increased to 1000, 2000, $3000,4000,5000$, and $6000 \mathrm{pg} / \mathrm{mL}$, respectively, when incubated with $25,50,75,100,125$, and $150 \mu \mathrm{g} / \mathrm{mL}$ PtNPs. The concentrations of IL-6 in cells incubated with minimal $(25 \mu \mathrm{g} / \mathrm{mL})$ and maximal $(150 \mu \mathrm{g} / \mathrm{mL})$ concentrations of PtNPs were 500 and $\sim 3000$ pg/mL, respectively, compared with the control, and fold copy numbers were significantly increased to 500,1000, 1500, 2000, 2500, and $3000 \mathrm{pg} / \mathrm{mL}$, respectively, when incubated with 25, 50, 75, 100, 125, and $150 \mu \mathrm{g} / \mathrm{mL}$ PtNPs. Our findings suggested that oxidative stress caused by ROS and nitric oxide is crucial for integrating inflammatory responses, the ER-stress response, and functional interactions between the ER and mitochondria. Another possible mechanism is that cytokines induced by PtNPs trigger calcium release from the ER and the accumulation of ROS, both of which interfere with protein folding and mitochondrial metabolism [106,107].
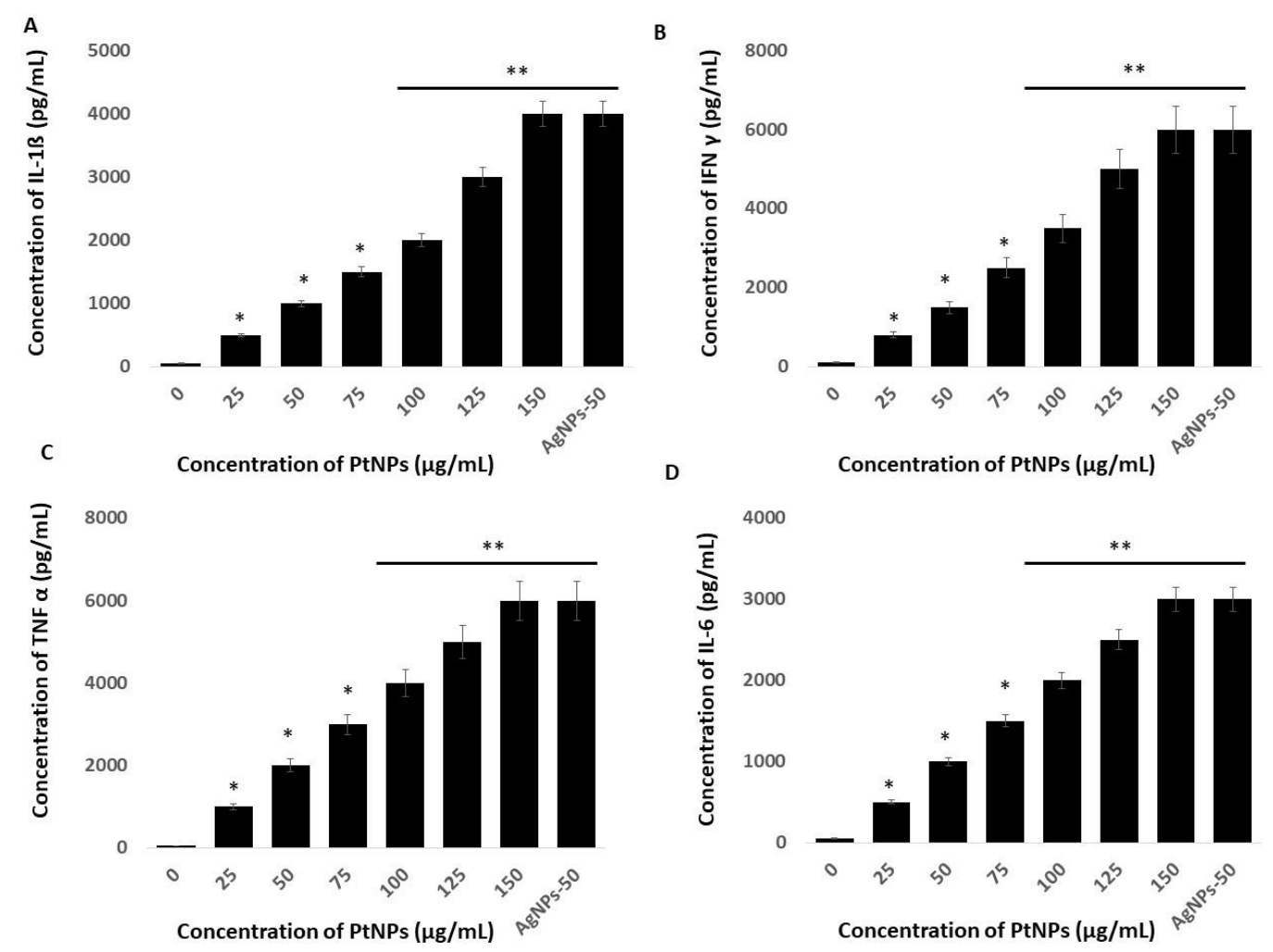

Figure 11. Effect of PtNPs on cytokine and chemokine levels. THP-1 cells were treated with various concentrations of PtNPs (25-150 $\mu \mathrm{g} / \mathrm{mL}$ ) for $24 \mathrm{~h}$. (A) IL-1 beta; (B) IFN $\gamma$, (C) TNF $\alpha$, and (D) IL-6 cytokine concentration was measured in the cell culture supernatant after PtNP treatment. Results are expressed as mean fold change \pm standard deviation from three independent experiments. The treated groups showed statistically significant differences from the control group by the Student's $t$-test $\left({ }^{*} p<0.05 ;{ }^{* *} p<0.01\right) .{ }^{*}$ significant; ** highly significant. 


\subsection{Gene Expression Profile Is Altered in THP-1 Cells Incubated with PtNPs}

Ultra-small PtNPs elicit cytotoxicity by inhibiting cell proliferation, and they decrease cell survival by disrupting mitochondrial functions. Therefore, we used RNA-Seq to analyze the underlying molecular mechanism through which PtNPs reduce cell viability and proliferation in THP-1 cells incubated without (control; $n=2)$ and with PtNPs $(n=2)$. Figure 12A shows that, among 441 differentially expressed genes (DEGs), the expressions of 143 and 298 genes were elevated and repressed, respectively. We investigated the biological consequences of these 441 DEGs using gene ontology (GO) analyses and found that genes associated immune responses (type I interferon signaling pathway and inflammatory responses), various antiviral responses (defense responses to virus and responses to viruses), responses to unfolded proteins, transfer RNA (tRNA) aminoacylation, L-serine biosynthesis, responses to mechanical stimulus, positive regulation of angiogenesis, and cellular response to hormone stimulus were changed (Figure 12B). Given that monocytic THP-1 cells were derived from a patient with acute monocytic leukemia, the differential expression of genes involved in GO biological processes (BP) is reasonable [108].
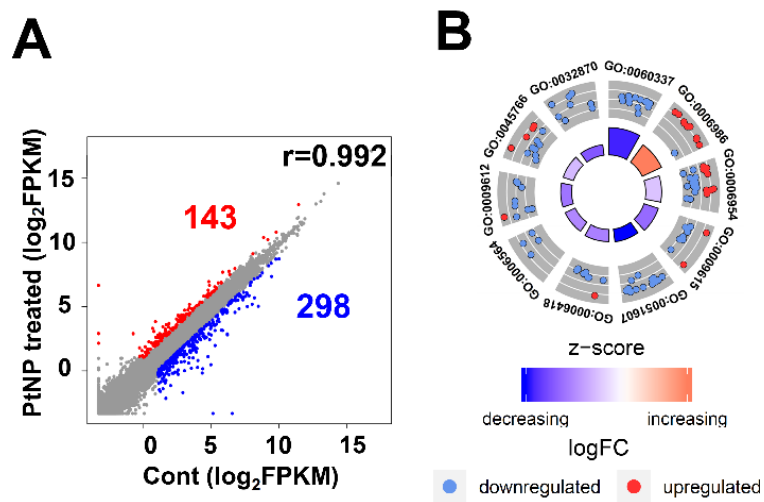

\begin{tabular}{|c|c|}
\hline ID & \begin{tabular}{c} 
Description \\
\hline GO:0060337
\end{tabular} \\
\hline GO:0006986 & type I interferon signaling pathway \\
\hline GO:0006954 & response to unfolded protein \\
\hline GO:0009615 & response to virus \\
\hline GO:0051607 & defense response to virus \\
\hline GO:0006418 & tRNA aminoacylation for protein translation \\
\hline GO:0006564 & L-serine biosynthetic process \\
\hline GO:0009612 & response to mechanical stimulus \\
\hline GO:0045766 & positive regulation of angiogenesis \\
\hline GO:0032870 & cellular response to hormone stimulus \\
\hline
\end{tabular}

Figure 12. PtNP treatment causes a change in gene expression. (A) Scatter plot representing expression profile of PtNP-treated and control samples. The red portion represents upregulated differentially expressed genes (DEGs) and the blue portion represents the downregulated DEGs in the PtNP-treated sample relative to the control sample. (B) A plot of gene ontology (GO) circle produced with biological processes of DEGs from the Database for Annotation, Visualization and Integrated Discovery (DAVID). Red dots and blue dots represent upregulated and downregulated genes, respectively. Each GO term is noted with a unique GO number.

\subsection{PtNP Treatment Changes Genes Related to Protein Misfolding and Mitochondrial Function}

We analyzed the GO of the up- and downregulated genes. Figure 13A shows that numerous immune-associated genes were repressed in THP-1 cells incubated with PtNPs. Incubation with PtNPs led to the upregulation of proteins involved in protein folding (responses to unfolded protein, protein folding, chaperone-mediated protein folding requiring cofactors, and protein refolding) in THP-1 cells (Figure 13A). Similarly, the downregulated genes were involved in protein synthesis (L-serine biosynthesis and tRNA aminoacylation for protein translation). These data are of interest because charged gold NPs can interact with peptides or proteins to form fibrils [109]. Such an interaction might result in massive protein misfolding that would inhibit cell growth and induce apoptosis. Ultra-small PtNPs also lead to cell apoptosis via mitochondrial dysfunction [18]. Our gene set enrichment analysis (GSEA) revealed that PtNPs induced aberrations in mitochondrial functions including oxidative phosphorylation, mitochondrial translation, and ATP synthesis-coupled electron transport (Figure 13B). 
A

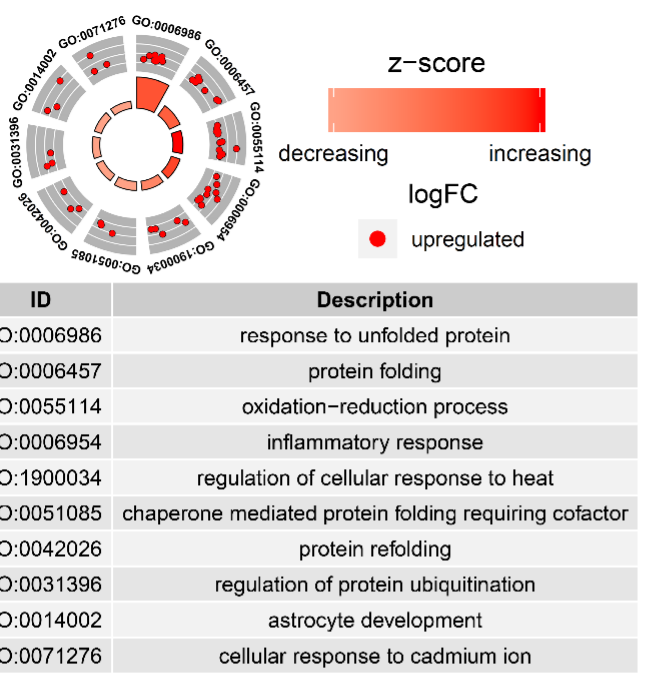

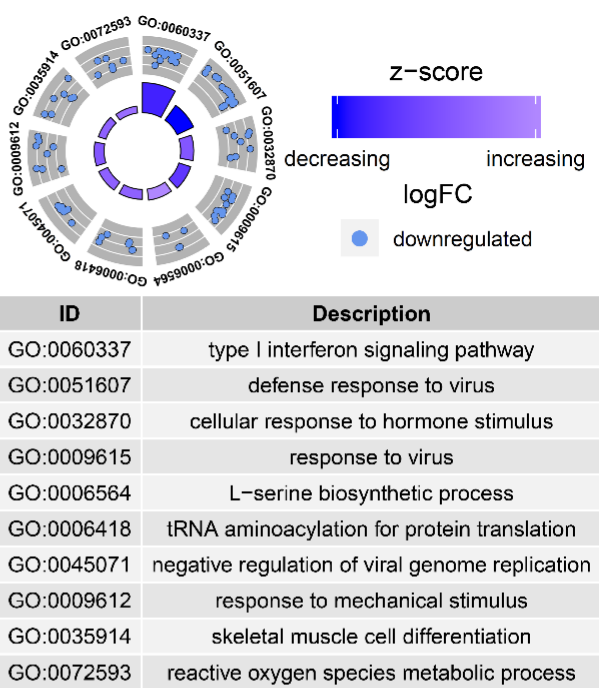

ATP synthesis coupled electron transport

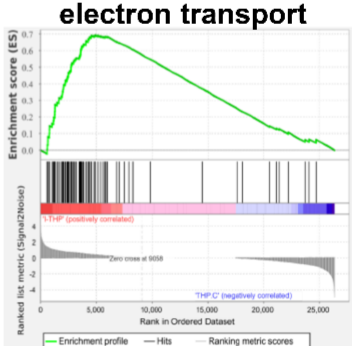

Figure 13. PtNPs alter genes involved in ER and mitochondrial dysfunctions. (A). GO circles analyzed with biological processes in DEGs from DAVID. The left circle displays highlighted GO terms of upregulated genes of PtNP-treated sample, and the right circle displays the terms of downregulated genes. Red dots and blue dots represent upregulated and downregulated genes, respectively. Each GO term is noted with a unique GO number. (B). Gene set enrichment analyses (GSEA) in the PtNP-treated sample. GSEAs associated with mitochondria dysfunctions are shown.

\subsection{PtNPs Impair Pathways Involved in Protein Synthesis}

We applied DEG to Kyoto Encyclopedia of Genes and Genomes (KEGG) pathway analyses to determine which biological pathways were altered by PtNPs. Genes associated with protein synthesis-related KEGG pathways (biosynthesis of amino acids and aminoacyl tRNA) and amino acid (glycine, serine, and threonine) metabolism were changed by PtNPs. When up- or downregulated DEG were applied separately, KEGG pathways of protein processing in the ER and antigen processing and presentation were identified in association with genes that were upregulated by PtNPs, whereas KEGG pathways of protein synthesis were identified in association with those that were downregulated by PtNPs (Figure 14A). Many genes associated with the IL-17 signaling pathway were changed by PtNPs (Figure 14B). Representative genes Fos-like Antigen 1 (FOSL1) and early Growth Response 1 (EGR1) involved in the IL-17 pathway were visualized using the Integrative Genomics Viewer (IGV) genome browser (Figure 14C). The IL-17 pathway plays preventive or promotive roles in some cancers by protecting against viral infection and inducing inflammatory responses [110]. 

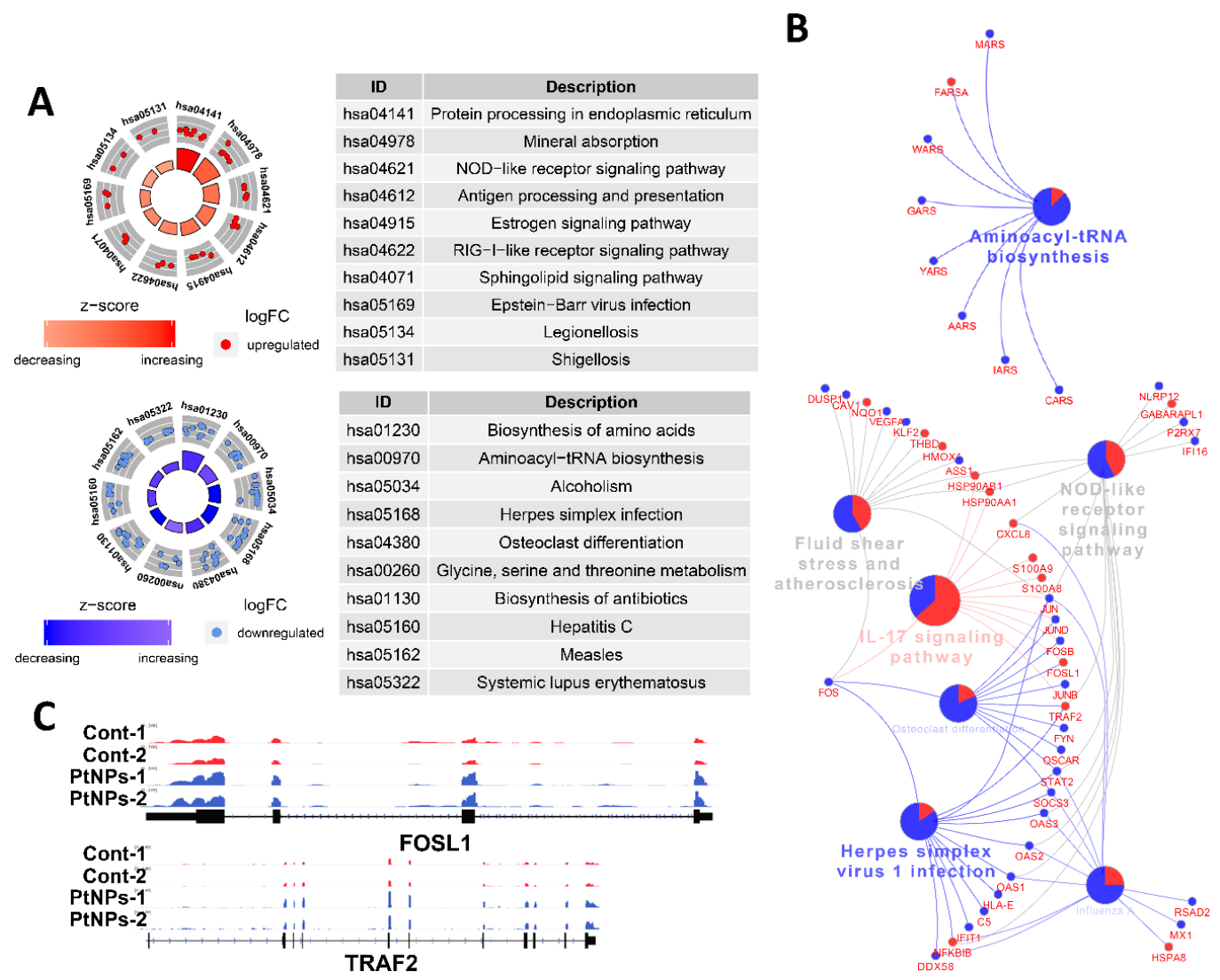

Figure 14. PtNPs impair pathways involved in protein synthesis. (A). Kyoto Encyclopedia of Genes and Genomes (KEGG) pathway analysis results of DEGs from DAVID. The upper circle displays highlighted pathways of upregulated genes of PtNP-treated sample, and the lower circle displays the terms of downregulated genes. Note that KEGG pathways related to proteins synthesis are mainly altered. (B). KEGG pathway analysis conducted with differentially expressed genes shown in the form of networks. Upregulated genes and downregulated genes are shown in red and blue colors, respectively. Gene networks associated with interleukin-17 (IL-17) signaling pathways and aminoacyl tRNA biosynthesis are changed by PtNPs. (C). Representative genes (FOSL1 and EGR1) involved in the IL-17 pathway are visualized.

\subsection{Transcriptional Regulation Is Impaired by PtNPS}

Given the changes in gene expression, we aimed to identify transcriptional factors (TFs) that are aberrantly changed and altered downstream of target genes by PtNPs. Analysis of networks between TFs and their downstream target genes revealed that PtNPs up- and downregulated the expression of seven and 29 TFs, respectively (Figure 15A). When applied to KEGG analysis, biological pathways such as IL-17 signaling, hormones/cytokines synthesis, and secretion and T-cell differentiation were altered (Figure 15B). Finally, interactions among TFs were analyzed, and the results are visualized in Figure 15C. We found that JUN proto-oncogene (JUN) is a key TF-modulating interconnector for other TFs (Figure 15D). Levels of JunB are reduced in association with apoptosis in cultured cells [111]. 


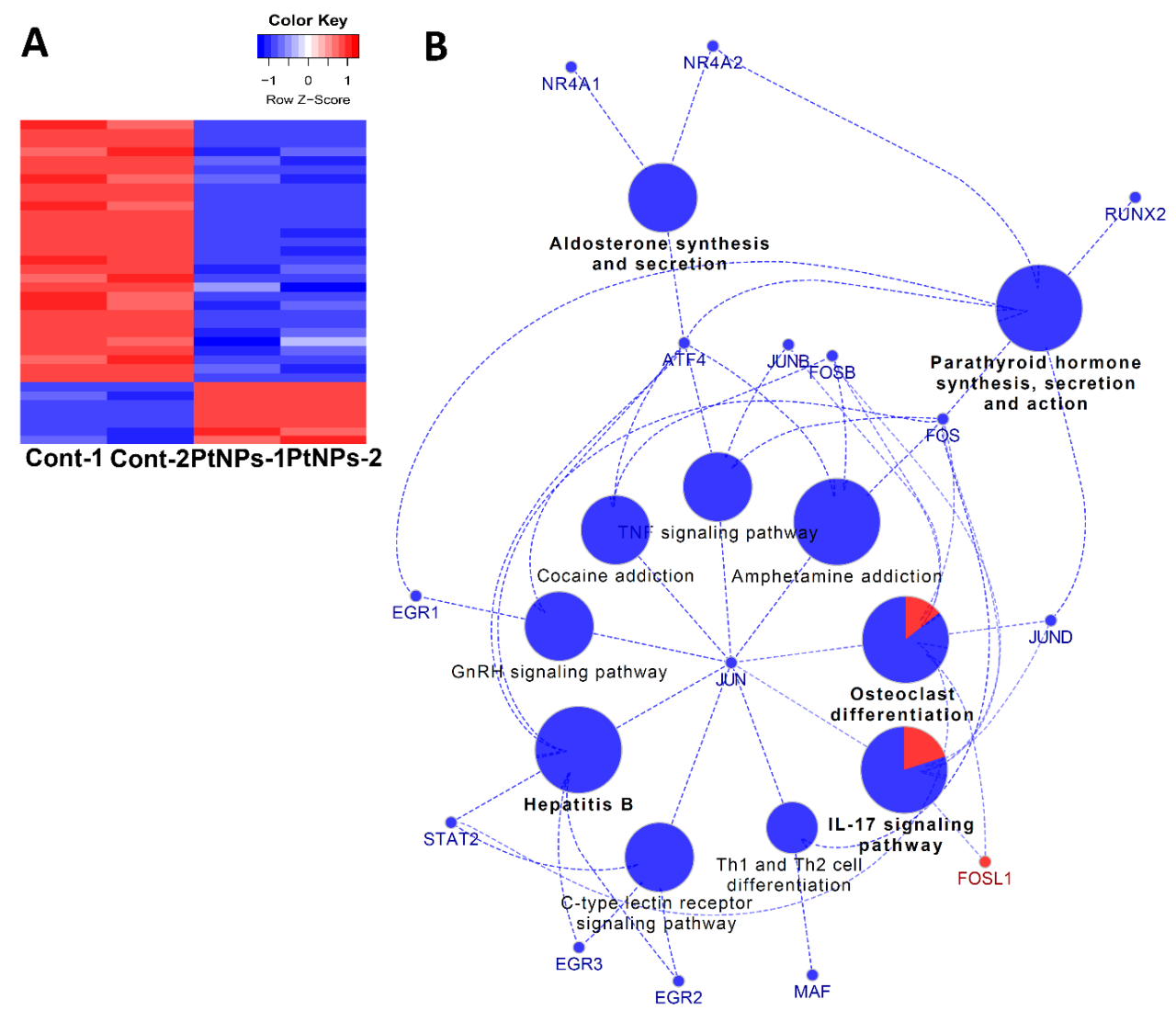

C
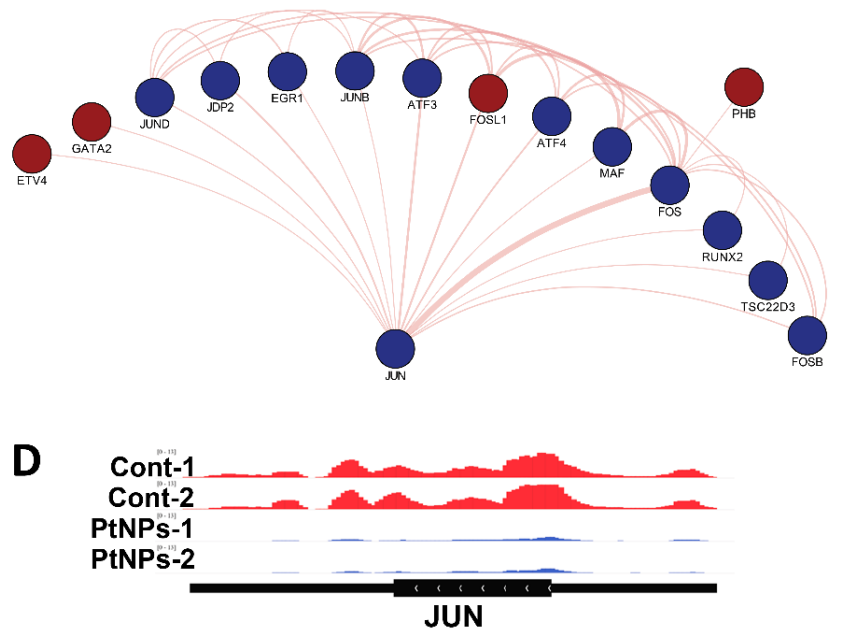

Figure 15. PtNPs change transcriptional networks. (A). Heatmap representing relative expression of differentially expressed transcription factors (TFs) in each sample. Seven and 29 TFs are enhanced and repressed by PtNPs. (B). KEGG pathway analysis conducted with differentially expressed transcription factors shown in the form of networks. JUN is identified as a key TF-modulating interconnector for other TFs regulating the KEGG pathways. TFs associated with pathways (IL-17 signaling, hormone production and secretion, hepatitis B infection, and T-cell differentiation) are altered. (C). Network showing interactions between JUN and other differentially expressed TFs. Dark-red and dark-blue nodes represent transcription factors with relatively higher and lower expression levels, respectively. Edge thickness represents the relative number of research references. (D). IGV genome browser images of expression level of JUN gene.

Previously, we demonstrated that apigenin-functionalized ultra-small PtNPs with an average size of $2 \mathrm{~nm}$ and significantly spherical in shape caused cytotoxicity in THP-1 cells, whereas 
lycopene-functionalized PtNPs showed that the anisotropic nature of particles exhibited a variety of shapes such as spherical, cubic, rectangular, triangular, octahedral, and tetrahedral, or truncated cubic, hexagonal, octahedral, and tetrahedral particles with an average size of 25 (range, 5-50) nm. With these particles, the study demonstrated cytotoxicity, apoptosis, inflammatory response, and transcriptomic and molecular pathway alterations in THP-1 cells. This study further described the impact of anisotropic nanoparticles on mitochondrial dysfunction through mitochondrial copy number, PCG-1 $\alpha$ expression, and ERS-mediated apoptosis. Interestingly, this study further discussed that lycopene-functionalized PtNPs could change the expression of genes involved in protein misfolding, mitochondrial function, protein synthesis, inflammatory responses, and transcription regulation.

\section{Materials and Methods}

\subsection{Materials}

The THP-1 cell line obtained from the American Type Culture Collection (ATCC; Manassas, VA, USA). All cells were cultured in $75-\mathrm{cm}^{2}$ tissue culture flasks (Corning Inc., Corning, NY, USA) at $37^{\circ} \mathrm{C}$ under a $5 \% \mathrm{CO}_{2}$ atmosphere and $95 \%$ relative humidity. Dried and hydrated hexachloroplatinic acid $\left(\mathrm{H}_{2} \mathrm{PtCl}_{6} \cdot 6 \mathrm{H}_{2} \mathrm{O}\right)$ was purchased from Sigma-Aldrich (St. Louis, MO, USA). Penicillin-streptomycin, trypsin- ethylenediaminetetraacetic acid (EDTA), Roswell Park Memorial Institute (RPMI)-1640 cell culture medium, fetal calf serum (FCS), and antibiotic/anti-mycotic reagents were obtained from Life Technologies/Gibco (Grand Island, NY, USA). Toxicology in vitro assay kits were purchased from Sigma-Aldrich. Reagents and kits to measure reactive oxygen species, malondialdehyde (MDA), protein carbonyl content, nitric oxide, and antioxidants, and all other chemicals were purchased from Sigma-Aldrich unless otherwise stated.

\subsection{Synthesis and Characterization of PtNPs}

We synthesized PtNPs by reducing $\mathrm{PtCl}_{6}{ }^{2-}$ ions to PtNPs in a mixture of $10 \mathrm{~mL}$ of $1 \mathrm{mg} / \mathrm{mL}$ lycopene and $90 \mathrm{~mL}$ of $1 \mathrm{mM}$ aqueous $\mathrm{H}_{2} \mathrm{PtCl}_{6} \cdot 6 \mathrm{H}_{2} \mathrm{O}$. Mixtures were maintained for $1 \mathrm{~h}$ at $100{ }^{\circ} \mathrm{C}$ (using a hotplate) in sealed flasks to avoid evaporation, as increasing temperatures catalyze the reduction process. Identical amounts of platinum solution and lycopene were separately maintained under the same reaction conditions for control experiments. The reduced platinum solution was sonicated for $10 \mathrm{~min}$ to separate platinum nanomaterials from biomolecules, then passed through a $0.2-\mu \mathrm{m}$ syringe filter. The reduced platinum was purified by repeated centrifugation at $5000 \times g$ for $30 \mathrm{~min}$, and the pellets were washed with distilled water to remove impurities. Purified PtNPs were characterized using UV-visible spectroscopy, X-ray diffraction (XRD), Fourier-transform infrared spectroscopy (FTIR), dynamic light scattering (DLS), and scanning (SEM) and transmission (TEM) electron microcopy.

\subsection{Cell Culture Conditions and PtNP Exposure}

THP-1 cells were cultured in RPMI-1640 cell medium supplemented with 10\% FCS, 2 mM L-glutamine, $10 \mathrm{mM}$ HEPES, $1 \mathrm{mM}$ pyruvate, $100 \mathrm{U} / \mathrm{mL}$ penicillin, and $0.1 \mathrm{mg} / \mathrm{mL}$ streptomycin (Sigma-Aldrich). The cells were sub-cultured usually twice a week with $1 \times 10^{6}$ viable cells $/ \mathrm{mL}$ and incubated at $37{ }^{\circ} \mathrm{C}$ in a $5 \% \mathrm{CO}_{2}$ atmosphere. The medium was replaced on the following day with $100 \mu \mathrm{L}$ of fresh medium, and the cells were incubated for $24 \mathrm{~h}$ before adding PtNPs. Experiments proceeded in 96-, 24-, and 12-well plates and in 100-mm cell culture dishes, as required. Cells were incubated with various concentrations of PtNPs or required doses of PtNPs.

\subsection{Cell Viability Assays}

Cell viability was measured using cell counting kit-8 (CCK-8; CK04-011; Dojindo Laboratories, Kumamoto, Japan). Briefly, THP-1 cells were seeded in 96-well flat-bottom culture plates containing various concentrations of PtNPs for $24 \mathrm{~h}$ at $37^{\circ} \mathrm{C}$ in a humidified $5 \% \mathrm{CO}_{2}$ incubator. The CCK-8 solution $(10 \mu \mathrm{L})$ was added to the wells, and the plates were incubated for a further $2 \mathrm{~h}$ at $37^{\circ} \mathrm{C}$. 
Absorbance was measured at $450 \mathrm{~nm}$ using a Multiskan FC microplate reader (Thermo Fisher Scientific, Waltham, MA, USA).

\subsection{BrdU Cell Proliferation Assays}

THP-1 cells were incubated with various concentrations of PtNPs for $24 \mathrm{~h}$, and then labeled BrdU was added to the medium $2 \mathrm{~h}$ before the end of the incubation. The cells were fixed, and amounts of incorporated BrdU were measured to determine cell proliferation using BrdU enzyme-linked immunosorbent assay (ELISA) kits as described by the manufacturer (Roche Molecular Biochemicals, Mannheim, Germany). The proliferation of THP-1 cells at $0 \mathrm{~h}$ was considered as $100 \%$.

\subsection{Cell Morphology Analysis}

THP- 1 cells were seeded in six-well plates $\left(2 \times 10^{5} /\right.$ well $)$ and incubated with $25-150 \mu \mathrm{g} / \mathrm{mL} \mathrm{PtNPs}$ for $24 \mathrm{~h}$. Cells cultured without PtNPs served as the control. Cell morphology was then assessed using an OLYMPUS IX71 optical microscope (Tokyo, Japan) with appropriate filter sets.

\subsection{Assessment of Membrane Integrity}

The membrane integrity of THP-1 cells was evaluated using LDH cytotoxicity detection kits. Briefly, the cells were incubated with various concentrations of PtNPs for $24 \mathrm{~h}$. Subsequently, $100 \mu \mathrm{L}$ of cell-free supernatant from each well was transferred in triplicate to 96-well plates, and $100 \mu \mathrm{L}$ of the $\mathrm{LDH}$ reaction mixture was added to each well. After a 3-h incubation under standard conditions, the optical density of the final solution was determined at a wavelength of $490 \mathrm{~nm}$ using a microplate reader.

\subsection{Assessment of Dead-Cell Protease Activity}

Dead-cell protease activity was assayed as described [112] in THP-1 cells incubated with various concentrations of PtNPs for $24 \mathrm{~h}$. Protease activity was determined by assessing associations between intracellular proteases and alanyl-alanyl phenylalanine-aminoluciferin, a luminogenic peptide substrate. Luminescence in each well after incubating the substrate $(5 \mu \mathrm{L})$ for 15 min at $37^{\circ} \mathrm{C}$ was measured using a luminescence counter (Perkin Elmer, Waltham, MA, USA). The degree of measured luminescence reflected dead-cell protease activity.

\subsection{Determination of ROS, MDA, Nitric Oxide (NO), and Carbonylated Protein Levels}

We estimated ROS as described previously [18]. THP-1 cells seeded into 24-well plates at a density of $5 \times 10^{4} /$ well were cultured for $24 \mathrm{~h}$, then washed twice with phosphate-buffered saline (PBS). Fresh medium containing various concentrations of PtNPs was added, and the cells were incubated for a further $24 \mathrm{~h}$. After supplementation with $20 \mu \mathrm{M}$ dichloro-dihydro-fluorescein diacetate (DCFH2-DA), the cells were incubated for $30 \mathrm{~min}$ at $37^{\circ} \mathrm{C}$ and rinsed with PBS. Thereafter, PBS $(2 \mathrm{~mL})$ was added to the wells, and fluorescence intensity was determined using a Gemini EM spectrofluorometer (Molecular Devices, Sunnyvale, CA, USA) at excitation and emission wavelengths of 485 and $530 \mathrm{~nm}$, respectively. Levels of MDA determined as thiobarbituric acid-reactive substances were assayed as described with modifications. The production of NO was spectrophotometrically quantified using the Griess reagent (Sigma-Aldrich St. Louis, MO, USA). Absorbance was measured at $540 \mathrm{~nm}$ and nitrite concentrations were determined using a calibration curve prepared with sodium nitrite as the standard [18]. Carbonylated protein content was measured as described previously [18].

\subsection{Measurement of Anti-Oxidative Markers}

The expression of oxidative and anti-oxidative stress markers was determined as described previously [38]. The anti-oxidative stress markers GSH, TRX, CAT, and SOD were quantified according to the manufacturer's instructions. THP-1 cells were cultured in $75-\mathrm{cm}^{2}$ culture flasks and incubated with various concentrations of PtNPs for $24 \mathrm{~h}$. The cells were scraped into chilled PBS, washed twice 
with $1 \times \mathrm{PBS}$ at $4{ }^{\circ} \mathrm{C}$ for six minutes each, and sedimented at $1500 \mathrm{rpm}$. Cell pellets were sonicated at $15 \mathrm{~W}$ for $10 \mathrm{~s}$ (three cycles) to obtain cell lysates. Supernatants were stored at $-70^{\circ} \mathrm{C}$.

\subsection{Determination of Mitochondrial Membrane Potential (MMP)}

We measured MMP according to the manufacturer's instructions (Molecular Probes, Eugene, OR, USA) using the cationic fluorescent indicator, JC-1 (Molecular Probes). THP-1 cells were incubated with various concentrations of PtNPs for $24 \mathrm{~h}$ followed by $10 \mu \mathrm{M} \mathrm{JC}-1$ at $37^{\circ} \mathrm{C}$ for $15 \mathrm{~min}$. The cells were washed and resuspended in PBS; then, fluorescence intensity was measured. Mitochondrial membrane potential was expressed as the ratio of the fluorescence intensity of JC- 1 aggregates to that of the monomers.

\subsection{Measurement of ATP}

THP-1 cells were incubated with various concentrations of PtNPs for $24 \mathrm{~h}$, and then ATP was measured according to the manufacturer's instructions (Catalog No., MAK135; Sigma-Aldrich St. Louis, MO, USA). Decreased levels of ATP indicated increased cytotoxicity.

\subsection{Analysis of Mitochondrial DNA Copy Number}

Mitochondrial dysfunction analysis was analyzed using real-time PCR amplification and by assessing mitochondrial copy numbers in THP-1 cells incubated with various concentrations of PtNPs for $24 \mathrm{~h}$. The following primers were used to determine copy numbers: mtDNA forward, CCTATCACCCTTGCCATCAT; mtDNA reverse, AGGCTGTTGCTTGTGTGAC. Nuclear DNA was quantified using the following primer set that detects the Pecam gene on chromosome 6: forward, ATGGAAAGCCTGCCATCATG; reverse, TCCTTGTTGTTCAGCATCAC [3].

\subsection{Reverse Transcription-Quantitative Polymerase Chain Reaction (RT-qPCR)}

THP-1 cells were incubated with various concentrations of PtNPs for $24 \mathrm{~h}$; then, total RNA was extracted using PicoPure RNA isolation kits (Arcturus Bioscience, Mountain View, CA, USA). Samples were prepared according to the manufacturer's instructions. RT-qPCR proceeded using a Vill7 device (Applied Biosystems, Foster City, CA, USA) and the double-stranded (ds)DNA-specific fluorescent dye SYBR Green (Applied Biosystems). Target gene expression was normalized to that of glyceraldehyde-3-phosphate dehydrogenase (GAPDH), which was not affected by PtNPs.

\subsection{Measurement of 8-Oxo-7,8-dihydro-20-deoxyguanosine (8-Oxo-Dg) and 8-Oxo-G Levels}

THP-1 cells were incubated with various concentrations of PtNPs for $24 \mathrm{~h}$; then, 8-oxo-dG content was determined as described previously [18] and as per the manufacturer's instructions (Trevigen, Gaithersburg, MD, USA). We prepared 8-OHdG and 8-OHG precoated well strips and then equilibrated them with all reagents at room temperature. Thereafter, either horseradish peroxidase (HRP)-conjugated 8-OHdG or HRP-conjugated 8-OHG antibody was added to standards or samples. All unbound reagents were removed after a 60-min incubation; then, absorbance was measured at $450 \mathrm{~nm}$ using an ELISA plate reader.

\subsection{Measurement of Cytokines}

THP-1 cells were incubated with PtNPs for $24 \mathrm{~h}$, and cytokines were evaluated using a multianalyte inflammatory cytokine ELISA array (Qiagen, Hilden, Germany). Sample values were normalized to control values and displayed as fold changes over control.

\subsection{Library Preparation and Sequencing}

THP- 1 cells were incubated with $\mathrm{IC}_{50}$ concentrations of PtNPs for $24 \mathrm{~h}$. Total RNA was isolated from control or treated cells using TRI reagent (Merck, Darmstadt, Germany). In total, 500 ng of total 
RNA was processed for the preparation of the whole-transcriptome sequencing library. Depletion of ribosomal RNA (rRNA) was performed using an MGIEasy RNA Directional Library Prep Kit (MGI Tech, Shenzhen, China) according to the manufacturer's instruction. The total RNAs were fragmented and copied into first-strand complementary DNA (cDNA) using reverse transcriptase and random primers. Strand specificity was achieved in the RT directional buffer, followed by second-strand cDNA synthesis. Subsequently, the cDNA fragments were ligated to sequencing adapter. The products were then purified and enriched with PCR amplification. The double-stranded library was quantified using a QauntiFluor ONE dsDNA System (Promega, Madison, WI, USA). The library was cyclized at $37^{\circ} \mathrm{C}$ for $60 \mathrm{~min}$, and digested at $37^{\circ} \mathrm{C}$ for $30 \mathrm{~min}$, followed by cleanup of the circularization product. To make a DNA nanoball (DNB), the library was incubated at $30^{\circ} \mathrm{C}$ for $25 \mathrm{~min}$ using a DNB enzyme. Finally, the library was quantified by a QauntiFluor single-stranded (ss)DNA System (Promega, Madison, WI, USA) and sequenced on the MGIseq system (MGI Tech, Shenzhen, China) with 100-bp paired-end reads.

\subsection{Bioinformatics}

Using the STAR (v2.6.1b, Cold Spring Harbor, NY, USA) tool, the sequencing reads were aligned and mapped to the UCSC human hg38 genome assembly. DEGs were obtained using Cuffnorm of Cufflinks (v2.2.1, Seattle, WA, USA). Scatter plot and gene ontology (GO) obtained using either DAVID (v6.8) or GOplot (v1.0.2, MLL Münchner Leukämielabor GmbH, Munich, Germany) tools were plotted in R package (v3.6.1). GSEA (v4.0.1, BROAD Institute, Cambridge, MA, USA) analysis was performed to show any phenotypic differences between control and PtNP treatment. IGV (v2.5.3, BROAD Institute, Cambridge, MA, USA) was used to visualize expression levels of DEGs. Transcription factors were determined with data from HumanTFDB (v3.0, Wuhan, China). Networks of transcription factors were analyzed in GeneMANIA tool (University of Toronto, ON, Canada). The heatmap was produced with the heatmap2 function of gplots (v3.0.1.1, Boehringer Ingelheim, Ingelheim, Germany) in R package. KEGG pathway analysis was performed using the ClueGO (v2.5.1, INSERM, Paris, France) plug-in for Cytoscape (v3.6.1, Institute of Systems Biology, Seattle, WA, USA). Protein-protein interactions were shown using the iRegulon (v1.3, Leuven, Belgium) plug-in for Cytoscape (v3.6.1, Institute of Systems Biology, Seattle, WA, USA).

\subsection{Statistical Analysis}

Independent experiments were repeated at least three times such that data are represented as means \pm standard deviation (SD) for all replicates within an individual experiment. Data were analyzed using the $t$-test, multivariate analysis, or one-way analysis of variance (ANOVA), followed by Tukey's test for multiple comparisons to determine the differences between groups denoted by an asterisk. The GraphPad Prism analysis software was used for all analyses.

\section{Conclusions}

Due to the immense growth of nanotechnology, PtNPs are widely applied due to their unique plasmonic properties. However, hazardous features and cytotoxicity to human cells, particularly monocytic cell lines, limited the medical and biological applications of PtNPs. Hence, we prepared anisotropic rather than homogeneous PtNPs using lycopene. We then investigated the effects of these PtNPs on THP-1 cells to determine their potential applications to consumer products. Our results showed that PtNPs potentially cause oxidative stress, which leads to a loss of cell viability, decreased proliferation, the induction of ROS, the upregulation of MDA, NO, protein carbonylation, ERS, apoptosis, and proinflammatory responses. Platinum NPs induced damage to the mitochondrial membrane potential, ATP synthesis, mitochondrial copy numbers, and biogenesis due to the generation of excess intracellular ROS. Excessive oxidative stress eventually caused an imbalance between intracellular pro- and antioxidants. Notably, PtNPs induced ERS-mediated cell death by increasing the expression of IRE1, PERK, ATF6, and ATF4, the apoptotic markers, p53, Bax, caspase 3, and the anti-apoptotic 
marker Bcl-2. These results indicated that PtNPs activate ERS, mitochondrial-mediated apoptosis, and proinflammatory responses by inducing the expression of IL-1 $\beta, \mathrm{IFN} \gamma, \mathrm{TNF} \alpha$, and IL-6. Transcriptomic and molecular pathway analyses of THP- 1 cells incubated with at IC $\mathrm{C}_{50}$ concentrations of PtNPs showed the expression of genes involved in protein misfolding, mitochondrial function, protein synthesis, inflammatory response, and transcription regulation. All these data were significantly associated with the findings of previous studies in vitro. Overall, our findings comprise a resource of transcriptional information upon which to base further mechanistic studies of PtNP toxicity. Collectively, PtNPs induce cell death through a specific mechanism of toxicity involving oxidative stress, mitochondrial dysfunction, ERS, and proinflammatory responses. Importantly, our genome-scale analysis reflected the phenotypes of THP-1 cells incubated with PtNPs in vitro. The proposed hypothesis confirmed the cytotoxic, apoptosis, and proinflammatory effects of anisotropic nanoparticles comparable with spherical nanoparticles. Mostly, anisotropic nanoparticles showed the capacity for tenacious and longer-term blood circulation, as well as higher in vivo targeting specificity, than their spherical counterparts. These features of anisotropic nanoparticles could enable the technology as an attractive platform for nanomedicine in biomedical applications. The toxic models of nanoparticles are tightly linked to the development of nanomedicines. Whereas uncontrolled exposure of human systems leads to toxicity, the selective induction of cytotoxicity in cancer cells could help to develop safe therapy for cancer. The increasing understanding of nanotoxicity studies would help to develop the safe design of nanomaterial-based cancer therapy. In particular, lycopene-functionalized PtNPs could change the expression of genes involved in protein misfolding, mitochondrial function, protein synthesis, inflammatory responses, and transcription regulation. These features of anisotropic nanoparticles could enable the technology as an attractive platform for nanomedicine in biomedical applications.

Author Contributions: S.G. conceptualized the idea and participated in the design and writing of the manuscript. M.J. synthesized and characterized nanomaterials and performed cellular assays. H.L. and H.Y. prepared samples for RNA-Seq analysis. Y.C., C.P. and J.T.D. performed RNA-Seq and downstream bioinformatics analysis. J.-H.K. analyzed and monitored the data. K.H. analyzed the data of RNA-Seq and downstream bioinformatics and reported on the transcriptomic and molecular pathway analysis. All authors have read and agreed to the published version of the manuscript.

Funding: This paper was supported by Konkuk University in 2017.

Acknowledgments: This paper was supported by Konkuk University in 2017.

Conflicts of Interest: The authors declare no conflicts of interest.

\section{References}

1. Kievit, F.M.; Zhang, M. Cancer nanotheranostics: Improving imaging and therapy by targeted delivery across biological barriers. Adv. Mater. 2011, 23, H217-H247. [CrossRef] [PubMed]

2. Namiki, Y.; Fuchigami, T.; Tada, N.; Kawamura, R.; Matsunuma, S.; Kitamoto, Y.; Nakagawa, M. Nanomedicine for cancer: Lipid-based nanostructures for drug delivery and monitoring. Acc. Chem. Res. 2011, 44, 1080-1093. [CrossRef] [PubMed]

3. Xu, R.; Wang, D.; Zhang, J.; Li, Y. Shape-dependent catalytic activity of silver nanoparticles for the oxidation of styrene. Chem. Asian J. 2006, 1, 888-893. [CrossRef] [PubMed]

4. Arvizo, R.R.; Bhattacharyya, S.; Kudgus, R.A.; Giri, K.; Bhattacharya, R.; Mukherjee, P. Intrinsic therapeutic applications of noble metal nanoparticles: Past, present and future. Chem. Soc. Rev. 2012, 41, 2943-2970. [CrossRef] [PubMed]

5. Gehrke, H.; Pelka, J.; Hartinger, C.G.; Blank, H.; Bleimund, F.; Schneider, R.; Gerthsen, D.; Brase, S.; Crone, M.; Turk, M.; et al. Platinum nanoparticles and their cellular uptake and DNA platination at non-cytotoxic concentrations. Arch. Toxicol. 2011, 85, 799-812. [CrossRef]

6. Horie, M.; Kato, H.; Endoh, S.; Fujita, K.; Nishio, K.; Komaba, L.K.; Fukui, H.; Nakamura, A.; Miyauchi, A.; Nakazato, T.; et al. Evaluation of cellular influences of platinum nanoparticles by stable medium dispersion. Metallomics 2011, 3, 1244-1252. [CrossRef] [PubMed]

7. McFarlane, S.; Manchee, C.P.K.; Silverstone, J.W.; Veinot, J.; Meldrum, A. Synthesis and Operation of Fluorescent-core Microcavities for Refractometric Sensing. J. Vis. Exp. 2013, 73, e50256. [CrossRef] 
8. Gurunathan, S.; Han, J.W.; Eppakayala, V.; Jeyaraj, M.; Kim, J.H. Cytotoxicity of biologically synthesized silver nanoparticles in MDA-MB-231 human breast cancer cells. BioMed Res. Int. 2013, 535796. [CrossRef]

9. Johnstone, T.C.; Suntharalingam, K.; Lippard, S.J. The Next Generation of Platinum Drugs: Targeted Pt(II) Agents, Nanoparticle Delivery, and Pt(IV) Prodrugs. Chem. Rev. 2016, 116, 3436-3486. [CrossRef]

10. Wang, Y.; Yang, J.; Liu, H.; Wang, X.; Zhou, Z.; Huang, Q.; Song, D.; Cai, X.; Li, L.; Lin, K.; et al. Osteotropic peptide-mediated bone targeting for photothermal treatment of bone tumors. Biomaterials 2017, 114, 97-105. [CrossRef]

11. Doherty, R.E.; Sazanovich, I.V.; McKenzie, L.K.; Stasheuski, A.S.; Coyle, R.; Baggaley, E.; Bottomley, S.; Weinstein, J.A.; Bryant, H.E. Photodynamic killing of cancer cells by a Platinum(II) complex with cyclometallating ligand. Sci. Rep. 2016, 6, 22668. [CrossRef]

12. Hussain, M.A.; Yang, M.; Lee, T.J.; Kim, J.W.; Choi, B.G. High density decoration of noble metal nanoparticles on polydopamine-functionalized molybdenum disulphide. J. Colloid Interface Sci. 2015, 451, $216-220$. [CrossRef] [PubMed]

13. Comfort, K.K.; Maurer, E.I.; Braydich-Stolle, L.K.; Hussain, S.M. Interference of silver, gold, and iron oxide nanoparticles on epidermal growth factor signal transduction in epithelial cells. ACS Nano 2011, 5, 10000-10008. [CrossRef] [PubMed]

14. Comfort, K.K.; Maurer, E.I.; Hussain, S.M. Slow release of ions from internalized silver nanoparticles modifies the epidermal growth factor signaling response. Colloids Surf. B Biointerfaces 2014, 123, 136-142. [CrossRef] [PubMed]

15. Bendale, Y.; Bendale, V.; Paul, S. Evaluation of cytotoxic activity of platinum nanoparticles against normal and cancer cells and its anticancer potential through induction of apoptosis. Integr. Med. Res. 2017, 6, 141-148. [CrossRef]

16. Brown, A.L.; Kai, M.P.; DuRoss, A.N.; Sahay, G.; Sun, C. Biodistribution and Toxicity of Micellar Platinum Nanoparticles in Mice via Intravenous Administration. Nanomaterials 2018, 8, 410. [CrossRef]

17. Gurunathan, S.; Jeyaraj, M.; Kang, M.H.; Kim, J.H. Graphene Oxide(-)Platinum Nanoparticle Nanocomposites: A Suitable Biocompatible Therapeutic Agent for Prostate Cancer. Polymers 2019, 11, 733. [CrossRef]

18. Gurunathan, S.; Jeyaraj, M.; Kang, M.H.; Kim, J.H. Tangeretin-Assisted Platinum Nanoparticles Enhance the Apoptotic Properties of Doxorubicin: Combination Therapy for Osteosarcoma Treatment. Nanomaterials 2019, 9, 1089. [CrossRef]

19. Gatto, F.; Moglianetti, M.; Pompa, P.P.; Bardi, G. Platinum Nanoparticles Decrease Reactive Oxygen Species and Modulate Gene Expression without Alteration of Immune Responses in THP-1 Monocytes. Nanomaterials 2018, 8, 392. [CrossRef]

20. Katsumi, H.; Fukui, K.; Sato, K.; Maruyama, S.; Yamashita, S.; Mizumoto, E.; Kusamori, K.; Oyama, M.; Sano, M.; Sakane, T.; et al. Pharmacokinetics and preventive effects of platinum nanoparticles as reactive oxygen species scavengers on hepatic ischemia/reperfusion injury in mice. Metallomics 2014, 6, 1050-1056. [CrossRef]

21. Asharani, P.V.; Lianwu, Y.; Gong, Z.; Valiyaveettil, S. Comparison of the toxicity of silver, gold and platinum nanoparticles in developing zebrafish embryos. Nanotoxicology 2011, 5, 43-54. [CrossRef]

22. Gurunathan, S.; Jeyaraj, M.; Kang, M.H.; Kim, J.H. The Effects of Apigenin-Biosynthesized Ultra-Small Platinum Nanoparticles on the Human Monocytic THP-1 Cell Line. Cells 2019, 8, 444. [CrossRef] [PubMed]

23. Kostova, I. Platinum complexes as anticancer agents. Recent Pat. Anti-Cancer Drug Discov. 2006, 1, 1-22. [CrossRef] [PubMed]

24. Stephens, I.E.; Bondarenko, A.S.; Perez-Alonso, F.J.; Calle-Vallejo, F.; Bech, L.; Johansson, T.P.; Jepsen, A.K.; Frydendal, R.; Knudsen, B.P.; Rossmeisl, J.; et al. Tuning the activity of $\mathrm{Pt}(111)$ for oxygen electroreduction by subsurface alloying. J. Am. Chem. Soc. 2011, 133, 5485-5491. [CrossRef] [PubMed]

25. Nellore, J.; Pauline, C.; Amarnath, K. Bacopa monnieri Phytochemicals Mediated Synthesis of Platinum Nanoparticles and Its Neurorescue Effect on 1-Methyl 4-Phenyl 1,2,3,6 Tetrahydropyridine-Induced Experimental Parkinsonism in Zebrafish. J. Neurodegener. Dis. 2013, 2013, 972391. [PubMed]

26. Alshatwi, A.A.; Athinarayanan, J.; Vaiyapuri Subbarayan, P. Green synthesis of platinum nanoparticles that induce cell death and G2/M-phase cell cycle arrest in human cervical cancer cells. J. Mater. Sci. Mater. Med. 2015, 26, 7. [CrossRef] [PubMed] 
27. Pelka, J.; Gehrke, H.; Esselen, M.; Turk, M.; Crone, M.; Brase, S.; Muller, T.; Blank, H.; Send, W.; Zibat, V.; et al. Cellular uptake of platinum nanoparticles in human colon carcinoma cells and their impact on cellular redox systems and DNA integrity. Chem. Res. Toxicol. 2009, 22, 649-659. [CrossRef]

28. Nakashima, A.; Higashisaka, K.; Kusabiraki, T.; Aoki, A.; Ushijima, A.; Ono, Y.; Tsuda, S.; Shima, T.; Yoshino, O.; Nagano, K.; et al. Autophagy is a new protective mechanism against the cytotoxicity of platinum nanoparticles in human trophoblasts. Sci. Rep. 2019, 9, 5478. [CrossRef]

29. Lebedova, J.; Hedberg, Y.S.; Odnevall Wallinder, I.; Karlsson, H.L. Size-dependent genotoxicity of silver, gold and platinum nanoparticles studied using the mini-gel comet assay and micronucleus scoring with flow cytometry. Mutagenesis 2018, 33, 77-85. [CrossRef]

30. Sahin, O.; Ozdemir, U.O.; Seferoglu, N.; Genc, Z.K.; Kaya, K.; Aydiner, B.; Tekin, S.; Seferoglu, Z. New platinum (II) and palladium (II) complexes of coumarin-thiazole Schiff base with a fluorescent chemosensor properties: Synthesis, spectroscopic characterization, X-ray structure determination, in vitro anticancer activity on various human carcinoma cell lines and computational studies. J. Photochem. Photobiol. B Biol. 2018, 178, 428-439.

31. Nejdl, L.; Kudr, J.; Moulick, A.; Hegerova, D.; Ruttkay-Nedecky, B.; Gumulec, J.; Cihalova, K.; Smerkova, K.; Dostalova, S.; Krizkova, S.; et al. Platinum nanoparticles induce damage to DNA and inhibit DNA replication. PLoS ONE 2017, 12, e0180798. [CrossRef]

32. Diabate, S.; Mulhopt, S.; Paur, H.R.; Krug, H.F. The response of a co-culture lung model to fine and ultrafine particles of incinerator fly ash at the air-liquid interface. Altern. Lab. Anim. 2008, 36, 285-298. [CrossRef] [PubMed]

33. Buchtelova, H.; Dostalova, S.; Michalek, P.; Krizkova, S.; Strmiska, V.; Kopel, P.; Hynek, D.; Richtera, L.; Ridoskova, A.; Adam, P.; et al. Size-related cytotoxicological aspects of polyvinylpyrrolidone-capped platinum nanoparticles. Food Chem. Toxicol. 2017, 105, 337-346. [CrossRef] [PubMed]

34. Labrador-Rached, C.J.; Browning, R.T.; Braydich-Stolle, L.K.; Comfort, K.K. Toxicological Implications of Platinum Nanoparticle Exposure: Stimulation of Intracellular Stress, Inflammatory Response, and Akt Signaling In Vitro. J. Toxicol. 2018, 2018, 1367801. [CrossRef] [PubMed]

35. Safar, R.; Doumandji, Z.; Saidou, T.; Ferrari, L.; Nahle, S.; Rihn, B.H.; Joubert, O. Cytotoxicity and global transcriptional responses induced by zinc oxide nanoparticles NM 110 in PMA-differentiated THP-1 cells. Toxicol. Lett. 2019, 308, 65-73. [CrossRef] [PubMed]

36. Jones, C.F.; Grainger, D.W. In vitro assessments of nanomaterial toxicity. Adv. Drug Deliv. Rev. 2009, 61, 438-456. [CrossRef] [PubMed]

37. Nguyen, D.; Duguet, E.; Bourgeat-Lami, E.; Ravaine, S. An Easy Way to Control the Morphology of Colloidal Polymer-Oxide Supraparticles through Seeded Dispersion Polymerization. Langmuir 2010, 26, 6086-6090. [CrossRef] [PubMed]

38. Dipankar, C.; Murugan, S. The green synthesis, characterization and evaluation of the biological activities of silver nanoparticles synthesized from Iresine herbstii leaf aqueous extracts. Colloid Surf. B 2012, 98, 112-119. [CrossRef]

39. Gurunathan, S.; Kang, M.H.; Kim, J.H. Combination Effect of Silver Nanoparticles and Histone Deacetylases Inhibitor in Human Alveolar Basal Epithelial Cells. Molecules 2018, 23, 2046. [CrossRef]

40. Borowik, A.; Banasiuk, R.; Derewonko, N.; Rychlowski, M.; Krychowiak-Masnicka, M.; Wyrzykowski, D.; Ziabka, M.; Woziwodzka, A.; Krolicka, A.; Piosik, J. Interactions of newly synthesized platinum nanoparticles with ICR-191 and their potential application. Sci. Rep. 2019, 9, 4987. [CrossRef]

41. Asharani, P.V.; Xinyi, N.; Hande, M.P.; Valiyaveettil, S. DNA damage and p53-mediated growth arrest in human cells treated with platinum nanoparticles. Nanomedicine (Lond) 2010, 5, 51-64. [CrossRef]

42. Prasek, M.; Sawosz, E.; Jaworski, S.; Grodzik, M.; Ostaszewska, T.; Kamaszewski, M.; Wierzbicki, M.; Chwalibog, A. Influence of nanoparticles of platinum on chicken embryo development and brain morphology. Nanoscale Res. Lett. 2013, 8, 251. [CrossRef] [PubMed]

43. Mohammadi, A.; Mohammadi, S.; Moghaddam, A.B.; Masoumi, V.; Walker, R.B. Electropolymerized Fluorinated Aniline-Based Fiber for Headspace Solid-Phase Microextraction and Gas Chromatographic Determination of Benzaldehyde in Injectable Pharmaceutical Formulations. J. Chromatogr. Sci. 2014, 52, 971-976. [CrossRef] [PubMed] 
44. Kutwin, M.; Sawosz, E.; Jaworski, S.; Hinzmann, M.; Wierzbicki, M.; Hotowy, A.; Grodzik, M.; Winnicka, A.; Chwalibog, A. Investigation of platinum nanoparticle properties against U87 glioblastoma multiforme. Arch. Med. Sci. 2017, 13, 1322-1334. [CrossRef] [PubMed]

45. Kutwin, M.; Sawosz, E.; Jaworski, S.; Wierzbicki, M.; Strojny, B.; Grodzik, M.; Chwalibog, A. Assessment of the proliferation status of glioblastoma cell and tumour tissue after nanoplatinum treatment. PLoS ONE 2017, 12, e0178277. [CrossRef] [PubMed]

46. Loan, T.T.; Do, L.T.; Yoo, H. Platinum Nanoparticles Induce Apoptosis on Raw 264.7 Macrophage Cells. J. Nanosci. Nanotechnol. 2018, 18, 861-864. [CrossRef] [PubMed]

47. Shiny, P.J.; Mukherjee, A.; Chandrasekaran, N. Haemocompatibility assessment of synthesised platinum nanoparticles and its implication in biology. Bioprocess Biosyst. Eng. 2014, 37, 991-997. [CrossRef]

48. Kim, W.K.; Kim, J.C.; Park, H.J.; Sul, O.J.; Lee, M.H.; Kim, J.S.; Choi, H.S. Platinum nanoparticles reduce ovariectomy-induced bone loss by decreasing osteoclastogenesis. Exp. Mol. Med. 2012, 44, 432-439. [CrossRef]

49. Rahman, I.; MacNee, W. Antioxidant pharmacological therapies for COPD. Curr. Opin. Pharmacol. 2012, 12, 256-265. [CrossRef]

50. Valdiglesias, V.; Fernandez-Bertolez, N.; Kilic, G.; Costa, C.; Costa, S.; Fraga, S.; Bessa, M.J.; Pasaro, E.; Teixeira, J.P.; Laffon, B. Are iron oxide nanoparticles safe? Current knowledge and future perspectives. J. Trace Elem. Med. Biol. 2016, 38, 53-63. [CrossRef]

51. Barcinska, E.; Wierzbicka, J.; Zauszkiewicz-Pawlak, A.; Jacewicz, D.; Dabrowska, A.; Inkielewicz-Stepniak, I. Role of Oxidative and Nitro-Oxidative Damage in Silver Nanoparticles Cytotoxic Effect against Human Pancreatic Ductal Adenocarcinoma Cells. Oxidative Med. Cell. Longev. 2018. [CrossRef]

52. Bedoya, F.J.; Salguero-Aranda, C.; Cahuana, G.M.; Tapia-Limonchi, R.; Soria, B.; Tejedo, J.R. Regulation of pancreatic beta-cell survival by nitric oxide: Clinical relevance. Islets 2012, 4, 108-118. [CrossRef]

53. Rainville, L.C.; Carolan, D.; Varela, A.C.; Doyle, H.; Sheehan, D. Proteomic evaluation of citrate-coated silver nanoparticles toxicity in Daphnia magna. Analyst 2014, 139, 1678-1686. [CrossRef] [PubMed]

54. Haase, A.; Rott, S.; Mantion, A.; Graf, P.; Plendl, J.; Thunemann, A.F.; Meier, W.P.; Taubert, A.; Luch, A.; Reiser, G. Effects of Silver Nanoparticles on Primary Mixed Neural Cell Cultures: Uptake, Oxidative Stress and Acute Calcium Responses. Toxicol. Sci. 2012, 126, 457-468. [CrossRef] [PubMed]

55. Haase, A.; Arlinghaus, H.F.; Tentschert, J.; Jungnickel, H.; Graf, P.; Mantion, A.; Draude, F.; Galla, S.; Plendl, J.; Goetz, M.E.; et al. Application of Laser Postionization Secondary Neutral Mass Spectrometry/Time-of-Flight Secondary Ion Mass Spectrometry in Nanotoxicology: Visualization of Nanosilver in Human Macrophages and Cellular Responses. ACS Nano 2011, 5, 3059-3068. [CrossRef] [PubMed]

56. Verano-Braga, T.; Miethling-Graff, R.; Wojdyla, K.; Rogowska-Wrzesinska, A.; Brewer, J.R.; Erdmann, H.; Kjeldsen, F. Insights into the Cellular Response Triggered by Silver Nanoparticles Using Quantitative Proteomics. ACS Nano 2014, 8, 2161-2175. [CrossRef] [PubMed]

57. Driessen, M.D.; Mues, S.; Vennemann, A.; Hellack, B.; Bannuscher, A.; Vimalakanthan, V.; Riebeling, C.; Ossig, R.; Wiemann, M.; Schnekenburger, J.; et al. Proteomic analysis of protein carbonylation: A useful tool to unravel nanoparticle toxicity mechanisms. Part. Fibre Toxicol. 2015, 12, 36. [CrossRef]

58. Butterfield, D.A.; Dalle-Donne, I. Redox Proteomics. Antioxid. Redox Signal. 2012, 17, 1487-1489. [CrossRef]

59. Dalle-Donne, I.; Aldini, G.; Carini, M.; Colombo, R.; Rossi, R.; Milzani, A. Protein carbonylation, cellular dysfunction, and disease progression. J. Cell. Mol. Med. 2006, 10, 389-406. [CrossRef]

60. Butterfield, D.A.; Perluigi, M.; Reed, T.; Muharib, T.; Hughes, C.P.; Robinson, R.A.S.; Sultana, R. Redox Proteomics in Selected Neurodegenerative Disorders: From Its Infancy to Future Applications. Antioxid. Redox Signal. 2012, 17, 1610-1655. [CrossRef]

61. Ergin, V.; Bali, E.B.; Hariry, R.E.; Karasu, C. Natural products and the aging process. Horm. Mol. Biol. Clin. Investig. 2013, 16, 55-64. [CrossRef]

62. Cabiscol, E.; Tamarit, J.; Ros, J. Protein carbonylation: Proteomics, specificity and relevance to aging. Mass Spectrom. Rev. 2014, 33, 21-48. [CrossRef] [PubMed]

63. Watanabe, J.; Yamada, M.; Niibe, K.; Zhang, M.; Kondo, T.; Ishibashi, M.; Egusa, H. Preconditioning of bone marrow-derived mesenchymal stem cells with $\mathrm{N}$-acetyl-L-cysteine enhances bone regeneration via reinforced resistance to oxidative stress. Biomaterials 2018, 185, 25-38. [CrossRef] [PubMed]

64. Chae, H.Z.; Kim, H.J.; Kang, S.W.; Rhee, S.G. Characterization of three isoforms of mammalian peroxiredoxin that reduce peroxides in the presence of thioredoxin. Diabetes Res. Clin. Pract. 1999, 45, 101-112. [CrossRef] 
65. Lillig, C.H.; Holmgren, A. Thioredoxin and related molecules-from biology to health and disease. Antioxid. Redox Signal. 2007, 9, 25-47. [CrossRef] [PubMed]

66. Nordberg, J.; Arner, E.S. Reactive oxygen species, antioxidants, and the mammalian thioredoxin system. Free. Radic. Biol. Med. 2001, 31, 1287-1312. [CrossRef]

67. Arner, E.S.; Holmgren, A. Physiological functions of thioredoxin and thioredoxin reductase. Eur. J. Biochem. 2000, 267, 6102-6109. [CrossRef] [PubMed]

68. Manke, A.; Wang, L.; Rojanasakul, Y. Mechanisms of nanoparticle-induced oxidative stress and toxicity. BioMed Res. Int. 2013, 942916. [CrossRef]

69. Ahamed, M.; Akhtar, M.J.; Raja, M.; Ahmad, I.; Siddiqui, M.K.; AlSalhi, M.S.; Alrokayan, S.A. ZnO nanorod-induced apoptosis in human alveolar adenocarcinoma cells via p53, survivin and bax/bcl-2 pathways: Role of oxidative stress. Nanomed. Nanotechnol. Biol. Med. 2011, 7, 904-913. [CrossRef]

70. Arora, S.; Jain, J.; Rajwade, J.M.; Paknikar, K.M. Cellular responses induced by silver nanoparticles: In vitro studies. Toxicol. Lett. 2008, 179, 93-100. [CrossRef]

71. Jin, C.Y.; Zhu, B.S.; Wang, X.F.; Lu, Q.H. Cytotoxicity of titanium dioxide nanoparticles in mouse fibroblast cells. Chem. Res. Toxicol. 2008, 21, 1871-1877. [CrossRef]

72. Bhatti, F.U.R.; Kim, S.J.; Yi, A.K.; Hasty, K.A.; Cho, H. Cytoprotective role of vitamin E in porcine adipose-tissue-derived mesenchymal stem cells against hydrogen-peroxide-induced oxidative stress. Cell Tissue Res. 2018, 374, 111-120. [CrossRef] [PubMed]

73. Pieczenik, S.R.; Neustadt, J. Mitochondrial dysfunction and molecular pathways of disease. Exp. Mol. Pathol. 2007, 83, 84-92. [CrossRef] [PubMed]

74. Almeer, R.S.; Ali, D.; Alarifi, S.; Alkahtani, S.; Almansour, M. Green Platinum Nanoparticles Interaction With HEK293 Cells: Cellular Toxicity, Apoptosis, and Genetic Damage. Dose -Response 2018, 16. [CrossRef] [PubMed]

75. Jiang, Q.; Liu, G.; Wang, X.Q.; Hou, Y.Q.; Duan, Y.H.; Wu, G.Y.; Yin, Y.L.; Yao, K. Mitochondrial pathway is involved in the protective effects of alpha-ketoglutarate on hydrogen peroxide induced damage to intestinal cells. Oncotarget 2017, 8, 74820-74835. [CrossRef]

76. Ben Safta, T.; Ziani, L.; Favre, L.; Lamendour, L.; Gros, G.; Mami-Chouaib, F.; Martinvalet, D.; Chouaib, S.; Thiery, J. Granzyme B-Activated p53 Interacts with Bcl-2 To Promote Cytotoxic Lymphocyte-Mediated Apoptosis. J. Immunol. 2015, 194, 418-428. [CrossRef]

77. Ismail, A.M.; In, L.L.A.; Tasyriq, M.; Syamsir, D.R.; Awang, K.; Mustafa, A.H.O.; Idris, O.F.; Fadl-Elmula, I.; Hasima, N. Extra virgin olive oil potentiates the effects of aromatase inhibitors via glutathione depletion in estrogen receptor-positive human breast cancer (MCF-7) cells. Food Chem. Toxicol. 2013, 62, 817-824. [CrossRef]

78. Xue, M.Z.; Momiji, H.; Rabbani, N.; Barker, G.; Bretschneider, T.; Shmygol, A.; Rand, D.A.; Thornalley, P.J. Frequency Modulated Translocational Oscillations of Nrf2 Mediate the Antioxidant Response Element Cytoprotective Transcriptional Response. Antioxid. Redox Signal. 2015, 23, 613-629. [CrossRef]

79. Chistiakov, D.A.; Sobenin, I.A.; Revin, V.V.; Orekhov, A.N.; Bobryshev, Y.V. Mitochondrial Aging and Age-Related Dysfunction of Mitochondria. BioMed Res. Int. 2014. [CrossRef]

80. Murphy, M.P. How mitochondria produce reactive oxygen species. Biochem. J. 2009, 417, 1-13. [CrossRef]

81. Beckman, K.B.; Ames, B.N. Detection and quantification of oxidative adducts of mitochondrial DNA. Methods Enzymol. 1996, 264, 442-453.

82. Valko, M.; Morris, H.; Cronin, M.T. Metals, toxicity and oxidative stress. Curr. Med. Chem. 2005, 12, 1161-1208. [CrossRef]

83. Mootha, V.K.; Bunkenborg, J.; Olsen, J.V.; Hjerrild, M.; Wisniewski, J.R.; Stahl, E.; Bolouri, M.S.; Ray, H.N.; Sihag, S.; Kamal, M.; et al. Integrated analysis of protein composition, tissue diversity, and gene regulation in mouse mitochondria. Cell 2003, 115, 629-640. [CrossRef]

84. Canto, C.; Auwerx, J. PGC-1 alpha, SIRT1 and AMPK, an energy sensing network that controls energy expenditure. Curr. Opin. Lipidol. 2009, 20, 98-105. [CrossRef]

85. Malhotra, J.D.; Kaufman, R.J. ER Stress and Its Functional Link to Mitochondria: Role in Cell Survival and Death. Cold Spring Harb. Perspect. Biol. 2011, 3, a004424. [CrossRef]

86. Amen, O.M.; Sarker, S.D.; Ghildyal, R.; Arya, A. Endoplasmic Reticulum Stress Activates Unfolded Protein Response Signaling and Mediates Inflammation, Obesity, and Cardiac Dysfunction: Therapeutic and Molecular Approach. Front. Pharmacol. 2019, 10. [CrossRef] 
87. Christen, V.; Fent, K. Silica nanoparticles induce endoplasmic reticulum stress response and activate mitogen activated kinase (MAPK) signalling. Toxicol. Rep. 2016, 3, 832-840. [CrossRef]

88. Shen, T.; Li, Y.; Chen, Z.G.; Liang, S.; Guo, Z.Y.; Wang, P.; Wu, Q.J.; Ba, G.; Fu, Q. CHOP negatively regulates Polo-like kinase 2 expression via recruiting C/EBP alpha to the upstream-promoter in human osteosarcoma cell line during ER stress. Int. J. Biochem. Cell B 2017, 89, 207-215. [CrossRef]

89. Schroder, M.; Kaufman, R.J. ER stress and the unfolded protein response. Mutat. Res. 2005, 569, $29-63$. [CrossRef]

90. Ron, D.; Walter, P. Signal integration in the endoplasmic reticulum unfolded protein response. Nat. Rev. Mol. Cell Biol. 2007, 8, 519-529. [CrossRef]

91. Tsujii, S.; Ishisaka, M.; Shimazawa, M.; Hashizume, T.; Hara, H. Zonisamide suppresses endoplasmic reticulum stress-induced neuronal cell damage in vitro and in vivo. Eur. J. Pharmacol. 2015, 746, 301-307. [CrossRef]

92. Go, B.S.; Kim, J.; Yang, J.H.; Choe, E.S. Psychostimulant-Induced Endoplasmic Reticulum Stress and Neurodegeneration. Mol. Neurobiol. 2017, 54, 4041-4048. [CrossRef]

93. Yoshida, H. ER stress and diseases. FEBS J. 2007, 274, 630-658. [CrossRef]

94. Wei, X.; Qi, Y.; Jia, N.; Zhou, Q.; Zhang, S.; Wang, Y. Hyperbaric oxygen treatment sensitizes gastric cancer cells to melatonin-induced apoptosis through multiple pathways. J. Cell. Biochem. 2018, 119, 6723-6731. [CrossRef]

95. Danial, N.N.; Korsmeyer, S.J. Cell death: Critical control points. Cell 2004, 116, 205-219. [CrossRef]

96. Puthalakath, H.; O’Reilly, L.A.; Gunn, P.; Lee, L.; Kelly, P.N.; Huntington, N.D.; Hughes, P.D.; Michalak, E.M.; McKimm-Breschkin, J.; Motoyama, N.; et al. ER stress triggers apoptosis by activating BH3-only protein Bim. Cell 2007, 129, 1337-1349. [CrossRef]

97. Galehdar, Z.; Swan, P.; Fuerth, B.; Callaghan, S.M.; Park, D.S.; Cregan, S.P. Neuronal apoptosis induced by endoplasmic reticulum stress is regulated by ATF4-CHOP-mediated induction of the Bcl-2 homology 3-only member PUMA. J. Neurosci. 2010, 30, 16938-16948. [CrossRef]

98. McCullough, K.D.; Martindale, J.L.; Klotz, L.O.; Aw, T.Y.; Holbrook, N.J. Gadd153 sensitizes cells to endoplasmic reticulum stress by down-regulating $\mathrm{Bcl} 2$ and perturbing the cellular redox state. Mol. Cell. Biol. 2001, 21, 1249-1259. [CrossRef]

99. Morishima, N.; Nakanishi, K.; Takenouchi, H.; Shibata, T.; Yasuhiko, Y. An endoplasmic reticulum stress-specific caspase cascade in apoptosis. Cytochrome c-independent activation of caspase-9 by caspase-12. J. Biol. Chem. 2002, 277, 34287-34294. [CrossRef]

100. Nakabeppu, Y.; Kajitani, K.; Sakamoto, K.; Yamaguchi, H.; Tsuchimoto, D. MTH1, an oxidized purine nucleoside triphosphatase, prevents the cytotoxicity and neurotoxicity of oxidized purine nucleotides. DNA Repair 2006, 5, 761-772. [CrossRef]

101. Nakabeppu, Y. Cellular levels of 8-oxoguanine in either DNA or the nucleotide pool play pivotal roles in carcinogenesis and survival of cancer cells. Int. J. Mol. Sci. 2014, 15, 12543-12557. [CrossRef]

102. Guan, R.; Kang, T.; Lu, F.; Zhang, Z.; Shen, H.; Liu, M. Cytotoxicity, oxidative stress, and genotoxicity in human hepatocyte and embryonic kidney cells exposed to ZnO nanoparticles. Nanoscale Res. Lett. 2012, 7 , 602. [CrossRef]

103. Gong, C.; Tao, G.; Yang, L.; Liu, J.; He, H.; Zhuang, Z. The role of reactive oxygen species in silicon dioxide nanoparticle-induced cytotoxicity and DNA damage in HaCaT cells. Mol. Biol. Rep. 2012, 39, 4915-4925. [CrossRef]

104. Magdolenova, Z.; Lorenzo, Y.; Collins, A.; Dusinska, M. Can Standard Genotoxicity Tests Be Applied to Nanoparticles? J. Toxicol. Envieon. Heal Part A 2012, 75, 800-806. [CrossRef]

105. Zhang, K.Z.; Kaufman, R.J. Identification and characterization of endoplasmic reticulum stress-induced apoptosis In vivo. Method Enzym. 2008, 442, 395-419.

106. Xue, X.; Piao, J.H.; Nakajima, A.; Sakon-Komazawa, S.; Kojima, Y.; Mori, K.; Yagita, H.; Okumura, K.; Harding, H.; Nakano, H. Tumor necrosis factor alpha (TNFalpha) induces the unfolded protein response (UPR) in a reactive oxygen species (ROS)-dependent fashion, and the UPR counteracts ROS accumulation by TNFalpha. J. Biol. Chem. 2005, 280, 33917-33925. [CrossRef]

107. Lin, M.L.; Chen, S.S.; Lu, Y.C.; Liang, R.Y.; Ho, Y.T.; Yang, C.Y.; Chung, J.G. Rhein induces apoptosis through induction of endoplasmic reticulum stress and Ca2+-dependent mitochondrial death pathway in human nasopharyngeal carcinoma cells. Anticancer. Res. 2007, 27, 3313-3322. 
108. Tsuchiya, S.; Yamabe, M.; Yamaguchi, Y.; Kobayashi, Y.; Konno, T.; Tada, K. Establishment and characterization of a human acute monocytic leukemia cell line (THP-1). Int. J. Cancer 1980, 26, 171-176. [CrossRef]

109. Wagner, S.C.; Roskamp, M.; Pallerla, M.; Araghi, R.R.; Schlecht, S.; Koksch, B. Nanoparticle-Induced Folding and Fibril Formation of Coiled-Coil-Based Model Peptides. Small 2010, 6, 1321-1328. [CrossRef]

110. McGeachy, M.J.; Cua, D.J.; Gaffen, S.L. The IL-17 Family of Cytokines in Health and Disease. Immunity 2019, 50, 892-906. [CrossRef]

111. Yan, M.J.; Yang, S.B.; Meng, F.B.; Zhao, Z.H.; Tian, Z.S.; Yang, P. MicroRNA 199a-5p induces apoptosis by targeting JunB. Sci. Rep. 2018, 8, 6699. [CrossRef]

112. Yuan, Y.G.; Wang, Y.H.; Xing, H.H.; Gurunathan, S. Quercetin-mediated synthesis of graphene oxide-silver nanoparticle nanocomposites: A suitable alternative nanotherapy for neuroblastoma. Int. J. Nanomed. 2017, 12, 5819-5839. [CrossRef]

(C) 2020 by the authors. Licensee MDPI, Basel, Switzerland. This article is an open access article distributed under the terms and conditions of the Creative Commons Attribution (CC BY) license (http://creativecommons.org/licenses/by/4.0/). 